\title{
Using AI-MCDM Model to Boost Sustainable Energy System Development: A Case Study on Solar Energy and Rainwater Collection in Guangdong Province
}

\author{
Sung-Lin Hsueh ${ }^{1}$, Yuan Feng ${ }^{1}$, Yue Sun ${ }^{1}$, Ruqi Jia ${ }^{1}$ and Min-Ren Yan ${ }^{2, *} \mathbb{C}$ \\ 1 Department of Art Design and Creative Industry, Nanfang College, 882, Wenquan Road, Conghua, \\ Guangzhou 510970, China; hsueh.sl@msa.hinet.net (S.-L.H.); von2000@126.com (Y.F.); \\ sinyocn@gmail.com (Y.S.); douzijrq0608@gmail.com (R.J.) \\ 2 College of Business, Chinese Culture University, No. 231, Sec 2, Jian Guo S. Road, Da-An District, \\ Taipei City 106, Taiwan \\ * Correspondence: ymr3@faculty.pccu.edu.tw
}

check for updates

Citation: Hsueh, S.-L.; Feng, Y.; Sun, Y.; Jia, R.; Yan, M.-R. Using AI-MCDM Model to Boost Sustainable Energy System Development: A Case Study on Solar Energy and Rainwater Collection in Guangdong Province. Sustainability 2021, 13, 12505. https: //doi.org/10.3390/su132212505

Academic Editor:

Wadim Strielkowski

Received: 23 September 2021

Accepted: 28 October 2021

Published: 12 November 2021

Publisher's Note: MDPI stays neutral with regard to jurisdictional claims in published maps and institutional affiliations.

Copyright: (c) 2021 by the authors. Licensee MDPI, Basel, Switzerland. This article is an open access article distributed under the terms and conditions of the Creative Commons Attribution (CC BY) license (https:// creativecommons.org/licenses/by/ $4.0 /)$.

\begin{abstract}
Rural areas in southern China receive ample rainfall annually as well as over $1600 \mathrm{~h}$ of annual sunshine. Despite a generally severe urban-rural development imbalance, these rural areas feature well-developed basic infrastructure and diverse economic activities. Rural revitalization policies in these areas have emphasized the development of cultural and ecological tourism, which has spurred economic development and given rise to a trend of villa construction. Residential buildings sit on large areas where natural resources are abundant. These advantages are conducive to the development and use of sustainable resources. This study proposes an incentive policy encouraging rural residents to renovate their buildings to include rainwater conservation and solar power generation. The Delphi method, an analytic hierarchy process, and fuzzy logic theory were combined to establish an AI-MCDM model, with applications of artificial intelligence and multiple-criteria decision making. Using Conghua District, Guangdong Province as an example, the study suggested that the model is beneficial to increasing the willingness of rural residents to reconstruct and renovate their residences, promoting the development of a low-carbon ecological region, Wenquan Township. We conducted the Delphi process twice to assess and validate incentives for installing natural resource conservation structures in agricultural areas. Nine criteria were identified, which can be divided into three main dimensions of participation situation, generating capacity, and storage facilities. The proposed AI-MCDM model developed using the Delphi-Fuzzy Analytic Hierarchy Process Model has high objectivity and can support rural areas in developing low-carbon, sustainable characteristics. The findings can serve as a reference for governments formulating incentives to encourage the installation of rainwater conservation and solar energy generation structures by rural households.
\end{abstract}

Keywords: rural revitalization; low carbon emission self-use residences; Delphi method; analytic hierarchy process; fuzzy logic theory; sustainable system development

\section{Introduction}

Climate change and sustainable energy system development have been critical issues affecting the world's sustainability. The 2019 United Nations Climate Change Conference (COP25) held discussions on crucial issues, including climate warming and air pollution. In addition to describing the current severity of abnormal climates and climate change around the world, these discussions detailed the risks of air pollution for human health. Since the industrial revolution in the nineteenth century, machines have been replacing human labor in production and have enabled the exploitation and use of natural resources (e.g., coal, oil, natural gas, and various minerals) in large quantities [1]. Although driving economic development in many countries, the industrial revolution and its aftermath have 
also generated environmental pollution and other challenges due to considerable $\mathrm{CO}_{2}$ emissions. This has resulted in aggravating global warming and climate change as well as irreversible, abnormal climate conditions (e.g., extreme cold, extreme heat, flooding, and drought) [2]. If not responded to seriously, climate disasters will continue to exacerbate. Conditions are particularly severe in underdeveloped countries and threaten the existence of numerous island nations. The 2019 annual report of the Intergovernmental Panel on Climate Change (IPCC-A UN agency) indicated that relative to the global temperature during the industrial revolution period, the current global temperature is approximately $1{ }^{\circ} \mathrm{C}$ higher [3]. Higher global temperatures lead to greater retaliation from nature. When the global warming has increased by $1.5^{\circ} \mathrm{C}$ [4-6], the climate disasters will have a greater impact on human life and property; when it increases by $1.5-2{ }^{\circ} \mathrm{C}[7-9]$, the world will be swept with foreseeable (e.g., stored-grain pest outbreaks [10], rising sea levels [11,12], droughts [13], and disturbance of forest ecosystems [14,15]) and unforeseeable climate disasters. The price of economic prosperity and rapid technological advancements, high $\mathrm{CO}_{2}$ emission, is a crucial environment governance issue that the world must confront [16]. Whether we can successfully curb global temperature increases is unknown. In February 2020, Antarctica registered a temperature above $20^{\circ} \mathrm{C}$, thereby posing a warning that the pace of melting ice and rising sea levels has quickened.

China is among one of the most impactful countries for sustainable energy system development. Rapid economic growth and the country's enormous domestic market have prompted China to become the world's largest production base. The country's overall economic status, technological development, social structure, city governance, public infrastructure, and environmental protection awareness underwent considerable change. Development of every kind has been integrated with a focus on green energy and environmentally friendly values. China is transforming industrial development that causes environmental pollution and has implemented strict improvement deadlines and schedules for industries that generate pollution to achieve sustainable urban and rural development with green environments.

Chinese society encountered various problems with the prosperity it attained through economic reform, such as environmental pollution and high $\mathrm{CO}_{2}$ emissions caused by industrial development and a severe gap between urban and rural development [17] (Table 1). To mitigate climate warming and high $\mathrm{CO}_{2}$ emissions, China has established relevant environmental policies and meticulously monitored their implementation. In addition, the country included actions against climate change in its 13th Five-Year Plan [18]. The pro-environmental behaviors that China has demonstrated [1] are conducive to countries reaching consensus on their roles in response to climate change [19].

Table 1. China's total $\mathrm{CO}_{2}$ emissions during 2000-2010.

\begin{tabular}{cccccccc}
\hline Year & $\mathbf{2 0 0 0}$ & $\mathbf{2 0 0 5}$ & $\mathbf{2 0 0 6}$ & $\mathbf{2 0 0 7}$ & $\mathbf{2 0 0 8}$ & $\mathbf{2 0 0 9}$ & $\mathbf{2 0 1 0}$ \\
\hline $\begin{array}{c}\mathrm{CO}_{2} \\
\begin{array}{c}\text { Actual emissions } \\
\mathrm{CO}_{2}\end{array}\end{array}$ & 34.0 & 55.5 & - & 65.3 & - & 72.1 & 83.2 \\
$\begin{array}{c}\text { Predicted emissions } \\
\text { Predic }\end{array}$ & - & - & 59.5 & 64.7 & 69.9 & 75.5 & 81.6 \\
\hline
\end{tabular}

In addition to causing abnormal climates globally, high $\mathrm{CO}_{2}$ emission levels severely influence the quantity and distribution of world water resources, such as through changes in surface and ground water [20]. The management of water resources is difficult due to inaccuracies and uncertainties persisting in regional water-resource-related information. Therefore, those responsible for planning and managing water resources constantly work in uncertain and ever-changing environments [21]. Already, the country with the largest consumption of water resources, China's total water consumption increases yearly [22]. The effect of global warming may further aggravate the long-term water shortage problems of the Beijing-Tianjin-Hebei region [23]; thus, effective planning for water resource management and development is imperative [24]. 
This study proposes an incentive policy encouraging rural residents to renovate their buildings to include rainwater conservation and solar power generation. An AI-MCDM model, with applications of artificial intelligence and multiple-criteria decision-making is proposed to support the sustainable energy system development. Using Conghua District, Guangdong Province as an example, the proposed model is beneficial to increasing the willingness of rural residents to reconstruct and renovate their residences, promoting the development of a low-carbon ecological region, Wenquan Township.

\section{Literature Review}

The literature review of relevant key issues is presented in the following sections: Section 2.1 introduces Wenquan, Guangdong Province; Section 2.2 offers a summary of energy consumption by buildings and households in China; Section 2.3 describes sustainable resource use subsidies for rural residences; Section 2.4 provides a compilation of initial criteria; and Section 2.5 discusses a multiple-criteria decision-making artificial intelligence model (MCDM-AI).

\subsection{Wenquan, Guangdong Province}

Guangdong, Guangxi, and Hainan provinces are the birthplaces of Lingnan culture and are embedded with rich cultural heritage sites. The rural revitalization strategies of the three provinces emphasize the redevelopment and application of traditional Lingnan cultural features. Wenquan, a township in Conghua District, a township neighboring Guangzhou City, the capital of Guangdong Province, was selected as the study case. The main reason we selected Wenquan is because Conghua is a national-level characteristic district that emphasizes ecological development. In December 2018, the first World Ecological Design Conference was held, and Conghua was chosen as the permanent host of the conference. This enabled Conghua to become China's first ecological design district that exhibits prosperous development [25]. The location of Wenquan Township in Conghua is depicted in Figure 1. Its location, area, population, average annual rainfall, and average annual sunshine hours of Wenquan are as follows:

(1) Latitude and longitude: latitude 113.55, longitude 23.57;

(2) Area: total area of Guangzhou City: $7434 \mathrm{~km}^{2}$; Conghua District is its largest district, accounting for $1974.5 \mathrm{~km}^{2}$;

(3) Population: the total population of Guangzhou City is approximately 14,904,400. Conghua District has the lowest permanent population in Guangzhou City, accounting for 647,100 residents, and has an urbanization ratio of $45.08 \%$ [26];

(4) Average annual rainfall: the average annual rainfall of Wenquan is $1652.5 \mathrm{~mm}$ [27];

(5) Average annual sunshine hours: $1690.2 \mathrm{~h} \mathrm{[28];}$

(6) Registered rural households: 105,700 households [29].

As the aforementioned data might suggest, Conghua has the smallest population and lowest population density of any township in Guangzhou City. Due to its expansive area and abundant rainfall and sunshine, Conghua boasts outstanding conditions for both collecting and reusing rainwater and developing solar energy. However, global warming has caused previously short, intermittent rainfall in regions with high annual average rainfall to be prolonged. This results in rainfall distribution, originally uniformly distributed, to become concentrated in specific periods at irregular intervals. It has also resulted in the occurrence of continuous rainfall; because the duration of rainfall has extended from one or two days to week-long rainfalls or longer, severe disasters commonly occur. As a result of climate change, the regularity of climate conditions has been disrupted. Any region that fails to collect sufficient rainwater faces constraints in water resources during droughts [30-32]. Townships with abundant water resources are suitable for buildings with self-sufficient water saving installations. These increase the regional water supply as well as provide benefits such as energy conservation and carbon reduction. 
Wen Quan Town

Annual Daylight : 1690.2 (hour / year)

- Annual Rainfall : 1652.5 (mm / year)

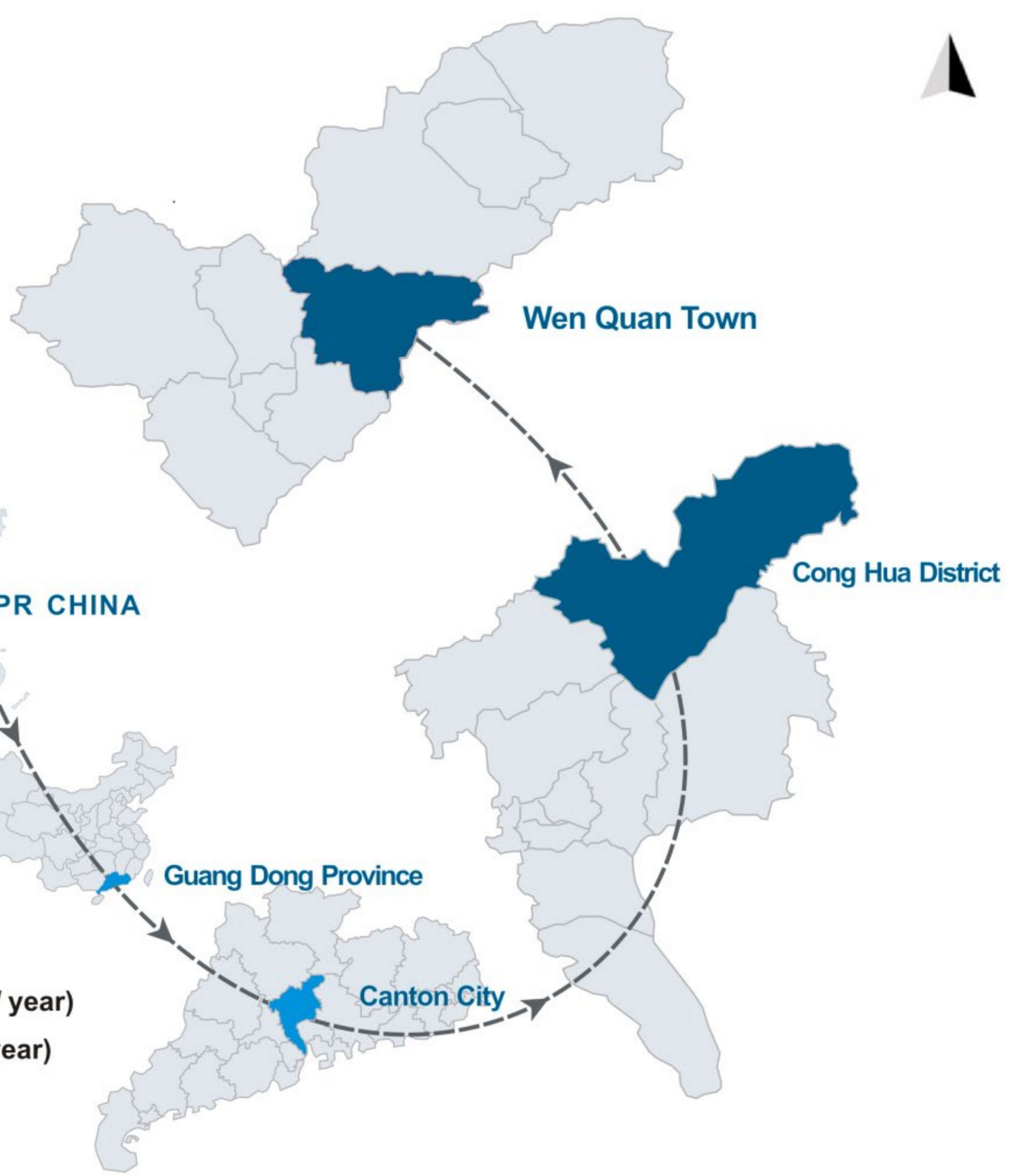

Figure 1. Relative location of Wenquan, Conghua District.

\subsection{Summary of Energy Consumption by Buildings and Residences in China}

Energy consumption by buildings contributes to the urban heat island effect [33-36], which is particularly severe in regions with a wide gap between urban and rural development. Due to their highly concentrated and abundant population, the demand for buildings in urban areas is many times that in rural areas. The construction industry is a high-polluting [37,38], high- $\mathrm{CO}_{2}$-emitting [39,40], and high-energy-consuming [41,42] industry that also severely threatens human health, such as through PM2.5 [43-45]. Approximately 16 billion $\mathrm{m}^{2}$ of land are converted to new building land annually in China, accounting for an energy utilization ratio of $33 \%$. Total building energy consumption constitutes approximately one-third of China's total energy consumption [46]; therefore, if the construction industry can reduce $\mathrm{CO}_{2}$ emissions, this would greatly contribute to slowing climate change. The 13th Five-Year Plan emphasizes concepts of ecologic civilization and green development and serves as China's implementation policy addressing climate change, energy conservation, and carbon emissions reduction. Additionally, the National Standard for Building Carbon Emission Calculation issued on 1 December 2019 is suitable for calculating carbon emissions during the production and transportation of materials, construction, demolition, and operating phases of new, expanded, and renovated civil buildings [47]. According to information from the National Bureau of Statistics in China, the proportion of building energy consumption in China's total energy consumption is increasing; it increased from 17.7\% (7.5 million tons of standard coal) in 2016 
to $28.0 \%$ (13 million tons of standard coal) in 2018. Figure 2 presents the proportion of China's building energy in total energy consumption during 2014-2018 (retrieved from www.Chyxx.com) [48].

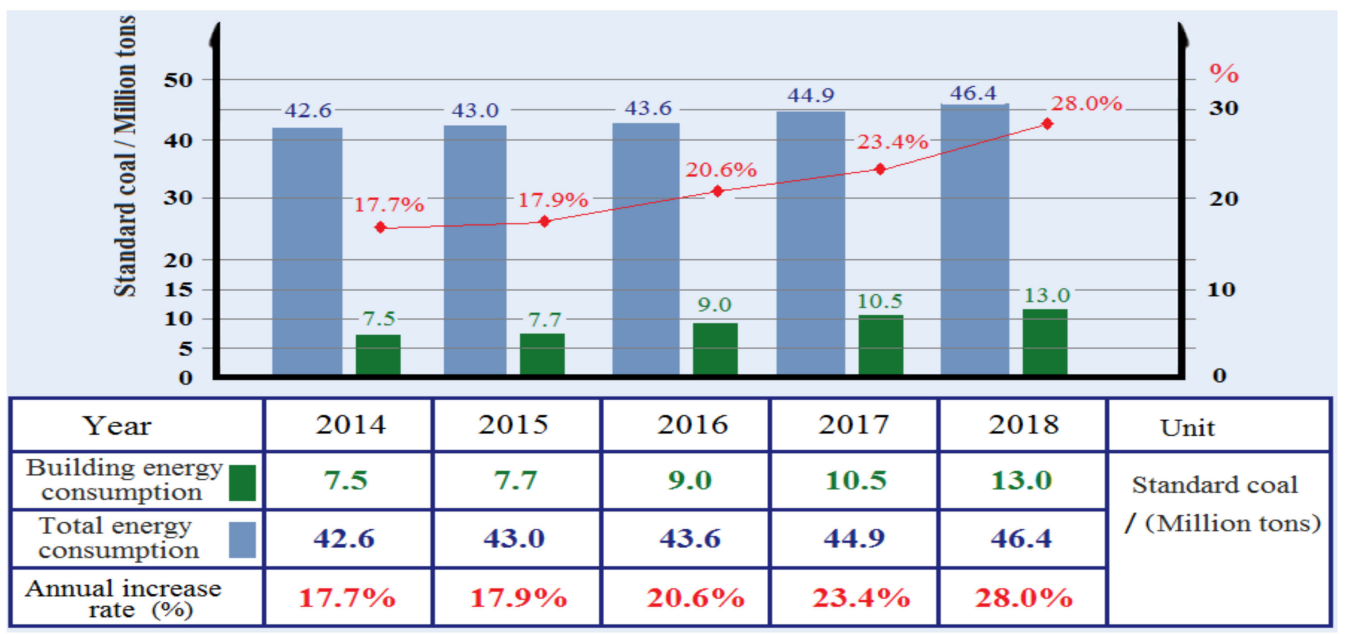

Figure 2. Proportion of building energy consumption in China's total energy consumption during 2014-2018.

In summary, the energy consumption of China's construction sector constitutes nearly $30 \%$ of the country's total energy consumption and is catching up to that of the United States, where it constitutes $40 \%$ of total energy consumption [49]. Therefore, energy policies in the building sector should focus on reducing $\mathrm{CO}_{2}$ emissions. Because the number of private buildings far exceeds that of public buildings, energy policies should provide corresponding subsidy measures to enable private building projects to abide by strict green regulations in design, procurement, building materials, and construction methods. This would incentivize cooperation with and acceptance of green policies in construction projects. Shazmin et al. argued that green building development is a focus of governments throughout the world. To encourage green building development, governments in various countries (e.g., Spain, Romania, Italy, Bulgaria, the United States, Canada, Malaysia, and India) have provided property tax assessment incentives for green buildings [50]. Energy conservation policy subsidies provided to building sectors in various countries include subsidies for green construction materials and in property taxes, as well as for the installation of solar water heaters, energy- and water-conserving household appliances, and rooftop photovoltaic power generation. The building energy consumption of household construction projects are divided into two categories according to the construction project life cycle. The first category comprises the planning and design, procurement and contracting, and construction and management phases; the second category consists of post-construction building use. Post-construction, residential buildings consume power daily. Households with higher income generally have higher energy demands, and household energy consumption is affected by the electronic appliance use habits of the household, as well as other factors [51]. These factors include whether the housing is a green building [52-54], whether it is equipped with a green roof [55-57], green façade [58], green infrastructure [59], solar photovoltaic systems [60-62], double-walled façade [63,64], double glass window [65,66], sunshade equipment [67], LED lamps [68], solar heating improvement [69], heating improvement [70,71], ventilation and air conditioning equipment [72], household energy and water conservation equipment [1], and whether it uses renewable energy [73].

Local governments have established subsidy policies to encourage household energy conservation. For example, the Xiangyang Housing and Urban-Rural Development Bureau [74] promulgated the "Notice for Existing Residential Buildings that Complete Energy Conservation Transformation Tasks" and the "Regulations on Energy Conservation 
Transformation Subsidy Use for Existing Residential Buildings in Xiangyang City" [74] to promote the understanding of energy conservation transformation goals and the practical methods available to households in the city. The urban and rural development bureaus of other provinces have provided corresponding subsidy measures promoting energy conservation in existing housing.

\subsection{Sustainable Resource Use Subsidies for Rural Residential Buildings and Regional Energy Development}

China's rapid economic growth has spurred standard-of-living improvements for urban and rural citizens alike, leading to significant growth in household electricity consumption. Increases in household electricity consumption have even surpassed those of industrial consumption, and most observers believe that energy conservation and high-efficiency energy consumption in the housing sector has enormous potential [75]. Meng et al. argued that in 2030, China's household electricity consumption will increase to $1060 \mathrm{kWh}$ per capita [76]. To adhere to national energy conservation policies, local governments at different levels have promulgated various application and review policies on energy conservation subsidies for residential buildings. For example, the comprehensive renovation of older residential communities in Ordos City involves a strict review of building service life, energy conservation value, and public demand and ensures the authenticity, accuracy, and feasibility of reported items through on-site investigations. In 2019, Ordos City reviewed and approved 45 items and 139 residential buildings for energy conservation projects [77]. The energy consumption of rural households makes a considerable contribution to the overall energy consumption of the country and has crucial influences on rural society and ecological environment construction. Wu et al. revealed that the energy consumption of rural citizens is closely related to their standard of living, poverty alleviation, atmospheric pollution, and personal health [78]. Additionally, Niu et al. indicated that to successfully promote energy structure transformation, China requires a further optimized energy structure to enhance its consumption efficiency, such as in the biogas and solar energy consumption of rural households, to determine the actual energy demand of rural households [79].

Coastal townships in southern China enjoy abundant sunshine and rainfall, granting rural residences in the region natural advantages to develop solar photovoltaic and stormwater reuse systems conducive to reducing $\mathrm{CO}_{2}$ emissions. Rosas-Flores et al. stated that Mexico is a country blessed with sunlight. If all urban and rural residential buildings in Mexico are equipped with solar photovoltaic systems, the country could conserve $39,750 \mathrm{GWh}$ of electricity annually, which is equal to $20.27 \mathrm{Tg}$ of $\mathrm{CO}_{2}$ emissions (3\% of Mexico's total $\mathrm{CO}_{2}$ emissions) [60]. This would enable sustainable energy development in rural areas and provide other practical benefits. Previous studied proposed that the economic competitiveness of solar energy storage systems can enhance rural energy access [80]. Rural residences tend to have more space, allowing for the installation of solar photovoltaic systems. Photovoltaic panels can be installed on residence rooftops as well as on the rooftops of farm machinery sheds and warehouses and in idle space. Furthermore, small-scale solar home systems can be installed in idle rural spaces to facilitate the development of cheap, clean energy. Because the upstream, midstream, and downstream supply chains of the solar photovoltaic industry in China have matured, solar photovoltaic systems have become a method to alleviate poverty. Currently, photovoltaic systems generate 19.1 million $\mathrm{kW}$ and provide support for 4.07 million households. In 2019, 1.5 billion $\mathrm{m}^{2}$ of clean heating surface was expanded to replace approximately 100 million tons of coal burned by households [81]. Solar energy home systems are a promising technology that can mitigate energy poverty and promote sustainable development through renewable energy. In emphasizing the development of renewable energy, China has promised to achieve the seventh sustainable development goal established by the UN [82].

The sustainable reuse of rainwater has also garnered attention. Rainwater can be used as water in daily life; for example, families can use rainwater tanks [83], a rainwater collection system [84], and conduct rainwater harvesting using buildings to store rainwater [85]. 
Urban water shortage is a universal issue. The use of road rainwater as a crucial resource for resolving global water shortages [86,87] and as a freshwater resource has received increasing attention. However, urban road surfaces consist of heavy metal deposits that enter road rainwater runoff and affect rainwater use safety [88]. By installing stormwater infrastructures in rural buildings, rainwater with less pollution can be directly retrieved and reused. Erected on wide-open land, rural residential buildings generally have sufficient idle space for the installation of green stormwater infrastructure [89]. Furthermore, rainwater processing systems and woodchip-biochar reactors with adequate flow control can be employed to eliminate pollutants and trace organic contaminants [90].

Because China is heavily populated with rural households, understanding the energy consumption characteristics of rural households is conducive to understanding relevant influential factors. It is also crucial to public policy design [91], beneficial to public participation and environmental governance [92], and facilitates improved energy development effectiveness in coastal rural areas. Due to China's developed solar photovoltaic industry and advanced installation technology, its regional governments have widely implemented solar photovoltaic subsidy policies for industries and households. Despite the wide development gap between coastal rural areas and urban regions, the living conditions of some rural residents may be superior to those of urban residents. The main source of livelihood for rural residents is no longer solely agricultural production. In fact, the revitalization and development goals of coastal rural areas in southern China combine ecotourism, cultural features, agricultural specialty products, and food and beverage themes. These rural areas engage in prosperous economic activities and have comprehensive hydraulic and electric public infrastructures. Therefore, they are less likely to prioritize household energy conservation as a development goal. To reduce $\mathrm{CO}_{2}$ emissions and resolve water shortage issues, this study proposes that coastal rural areas in China have sunlight and rainwater resource conditions conducive to including solar photovoltaic systems and stormwater reuse as development items for rural revitalization. Furthermore, this study proposes that residential buildings that comply with promoted policies be provided with subsidies for renovation or new construction. By adopting an objective, quantitative MCDA-AI model to evaluate the necessary amount of subsidies, this study demonstrates the decision-making support functions of MCDA-AI, using rural buildings in Wenquan as an example.

\subsection{Compilation of Initial Criteria}

Initial criteria are the basis of reference in the process of designing Delphi questionnaires. According to the literature review, we compiled core content with policies, natural resources, sunshine and rainwater amounts, and the demands of rural residents as initial criteria, for 17 criteria that can be divided into 4 dimensions as follows:

(1) Public policy design: reduce $\mathrm{CO}_{2}$ emissions (pollution prevention), environmental governance, energy consumption characteristics, subsidy budgeting, implementation benefits;

(2) Solar electricity: rooftop solar energy generators, solar photovoltaic systems, solar home systems (maintenance and transaction);

(3) Rainwater collection: rainwater tanks, rainwater collection pool, building rainwater harvesting, rainwater collection system, green stormwater infrastructure;

(4) Public attitude (Public demand): public participation, environmental awareness (pro-environmental), subsidy method, subsidy amount.

\subsection{Multi-Attribute Decision-Making Artificial Intelligence Model: Delphi Fuzzy-Delphi Analytic Hierarchy Process Model}

The MCDM-AI model is a support tool that aids decision makers in reducing decisionmaking risk. It has been widely applied in various decision-making fields and in research and application in renewable energy and sustainable energy fields such as Urban Environmental Quality [93], environmental education [94], evaluating energy storage systems for grid applications [95], assessing sustainable alternatives for power generation [96], the 
assessment of bioenergy production technologies [97], sustainability evaluations of concentrated solar power projects [98], the assessment of household biogas digester programmers in rural areas [99], urban greenways [100], and urban renewal [101]. MCDM-AI models have high objectivity and employ advanced scientific computing, quantitative analysis, and qualitative analysis functions. In addition to boasting high adaptiveness, these models are convenient to use and maintain.

Regardless of scale, every construction project is unique and entails multidimensional decision-making problems. Previous studies proposed that MCDM is suited to solving decision-making problems encountered in the building design process and can also be used to address contradictory standards that involve multiple stakeholders [102]. MCDM is also applicable in devising comprehensive solutions for repair or construction issues in self-use residential buildings. This includes decision-making problems that involve the renovation of individual and multiple household buildings. Integrating the expert group decision-making of the Delphi method, the multiple criteria analysis function of the analytic hierarchy process (AHP), and fuzzy logic theory to decipher fuzzy semantics, we combined the three methods to accommodate the shortcomings of each and constructed a suitable MCDA-AI decision-making tool, namely, the Delphi Fuzzy (DFuzzy)-Delphi Analytic Hierarchy Process (DAHP) model. These three methods comprise qualitative and quantitative analytic functions and perfectly accommodate each other. Table 2 details the functions and features of MCDA; Figure 3 depicts the MCDA process.

Table 2. Functions and features of the multiple-criteria decision analysis artificial intelligence.

\begin{tabular}{|c|c|c|}
\hline Method & Functions and Features & Support Tool \\
\hline Delphi & $\begin{array}{l}\text { The Delphi process is employed to conduct qualitative analysis } \\
\text { of data collected during the literature review. This is to acquire } \\
\text { criteria consistently identified by Delphi experts for use with } \\
\text { fuzzy logic and the AHP. }\end{array}$ & Delphi questionnaire \\
\hline Fuzzy logic & $\begin{array}{l}\text { The fuzzy logic theory is applied to establish the fuzzy logic } \\
\text { inference system (FLIS). The FLIS is capable of inferencing } \\
\text { algorithm functions, evaluating input criteria combinations, } \\
\text { computing scientific inference algorithms, and converting } \\
\text { outputs into quantified values, namely, } f(x) \text {. In addition, the } \\
\text { FLIS is capable of computing the fuzzy logic of human speech, } \\
\text { imprecise input data, and criteria with different units. }\end{array}$ & MATLAB software \\
\hline AHP & $\begin{array}{l}\text { To achieve effective questionnaire investigation information and } \\
\text { to compute the relative weights }(w) \text { of each criterion, this study } \\
\text { designed the paired comparison questionnaire for the AHP } \\
\text { through the Delphic process using expert-validated criteria. }\end{array}$ & $\begin{array}{l}\text { Paired comparison questionnaire } \\
\text { and AHP equation }\end{array}$ \\
\hline DFuzzy-DAHP & $\begin{array}{l}\text { This study employed the Delphi Fuzzy (DFuzzy) model to } \\
\text { compute the overall quantitative proportions of the assessment } \\
\text { results. Subsequently, the Delphi AHP (DAHP) model was } \\
\text { adopted to compute the quantitative proportion of each } \\
\text { criterion to analyze details in the decision-making process and } \\
\text { clarify the existing root problems. }\end{array}$ & $\begin{array}{c}f\left(y_{s}\right)=f\left(x_{s}\right) \times\left(\Sigma w_{i}\right) \\
s=1 \sim j ; i=1 \sim n\end{array}$ \\
\hline
\end{tabular}




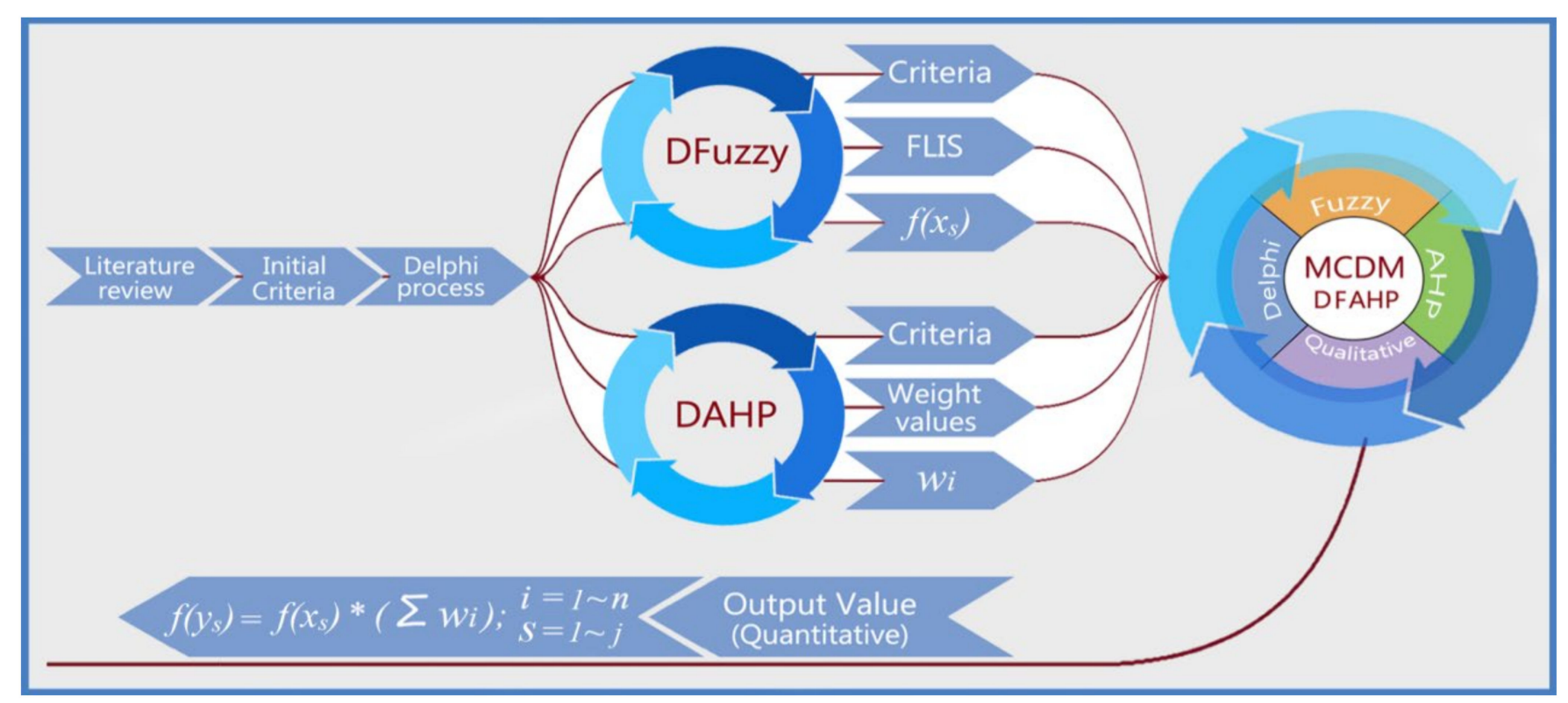

Figure 3. Multiple-criteria decision analysis artificial intelligence process.

\section{Overview of the Delphi Fuzzy-Delphi Analytic Hierarchy Process}

The DFuzzy-DAHP model is detailed in the following sections. Section 3.1 summarizes the Delphi, fuzzy logic, and AHP methods. Section 3.2 outlines the development of the DFuzzy model, which comprised the validating criteria for model construction (Section 3.2.1) and defining the model's parameters, and offers an overview of the FLISsimulated algorithm (Section 3.2.2). Section 3.3 describes the development of the DAHP model. Section 3.4 explains the development and application of the DFAHP model.

\subsection{Summary of Delphi, Fuzzy Logic, and AHP Methods}

The Delphi method was developed by the RAND Corporation in the United States and has been widely applied in various fields. It is a group decision-making questionnaire method conducted anonymously by experts. The Delphi expert questionnaire method is often confused as an expert field research method. Differences between the two are listed in Table 3. The Delphi method is an investigative method conducted using anonymous feedback. The process consists of first acquiring expert opinions regarding all expected problems. The expert opinions are compiled and inducted, and the questionnaire is revised. Subsequently, experts receive anonymous feedback from other experts regarding their responses. The revised questionnaire is then returned to experts to acquire their opinions once again. The process is repeated until the expert responses reach a consensus. The Delphi method is applicable to sustainable energy, ecological, and construction challenges, including the Developing sustainable building assessment scheme [103], Public policies for smart grids [104], Multi-faceted energy planning [105], the Development of wave and tidal energy technologies [106], and the Non-domestic building refurbishment scheme [107]. 
Table 3. Comparison of Delphi and expert field research methods.

\begin{tabular}{ccc}
\hline Concept & Delphi Method & Field Research (Expert Investigation) \\
\hline Questionnaire & Delphi expert questionnaire & Field questionnaire \\
\hline Participants & $\begin{array}{c}\text { Experts with industrial, public sector, or academic } \\
\text { backgrounds with extensive experience in their field. }\end{array}$ & $\begin{array}{c}\text { Experts are generally invited according to } \\
\text { researchers' rigorousness. }\end{array}$ \\
\hline Investigation method & $\begin{array}{c}\text { Anonymous mail, direct interviews, } \\
\text { or phone interviews }\end{array}$ & $\begin{array}{c}\text { Mail, direct interviews, or phone interviews } \\
\text { that need not be anonymously nor } \\
\text { individually conducted. }\end{array}$ \\
\hline Process & $\begin{array}{c}\text { Collecting opinions, compiling and inducting data, } \\
\text { and comparing opinions. If the expert opinions are } \\
\text { inconsistent, the questionnaire is redesigned. The } \\
\text { process is repeated until the experts reach a consensus. }\end{array}$ & $\begin{array}{c}\text { Collecting opinions, compiling and inducting } \\
\text { data, and conducting statistical analysis }\end{array}$ \\
\hline Feature & Qualitative analysis & Qualitative analysis \\
\hline Data characteristics & $\begin{array}{c}\text { Independent. Only opinions that researchers have } \\
\text { reached a consensus on are collected. }\end{array}$ & $\begin{array}{c}\text { Requires further statistical analysis techniques } \\
\text { to understand the independence of the data. }\end{array}$ \\
\hline
\end{tabular}

Fuzzy logic theory is part of the AI field. In 1965, Zadeh proposed the fuzzy logic methodology, which was followed by the practical application of fuzzy logic, such as with the concepts of fuzzy sets [108] and "Fuzzy logic = Computing with words" [109]. The fuzzy set of $\{0,1\}$ is composed of infinite continuous elements, whereas the crisp sets $\{0,1\}$ of different computer information technologies are comprised of two elements, namely, 0 and 1 . As "Fuzzy logic theory = Computing with words" suggests, fuzzy logic can be used to process fuzzy semantics. Fuzzy logic processes imprecise adjectives and semantics by using the membership function to detail whether the information is closer to 0 or 1 , thereby converting the human thinking model into an inference computation function. Therefore, fuzzy logic is applicable to processing imprecise information and simultaneously computing different semantics, sets of different sizes, and different units-for example, in the computation of two sets with different data characteristics as follows:

(1) A set with three elements (tall, standard, and short) measured in meters.

(2) A set with five elements (very heavy, heavy, normal, light, and very light) measured in kilograms.

Conventional mathematical computation methods have difficulty simultaneously processing such data sets with different characteristics. However, fuzzy logic data processing differs from equations used in conventional mathematical computation methods by using inference algorithm techniques. This enables fuzzy logic to establish comprehensive assessment models using data with different characteristics, converting the input scenario of each item into inference information. Scientific fuzzy logic inference algorithm models are applicable to conducting quantified decision making with items with different characteristics [1]. Fuzzy logic theories such as Delphi "defuzzification" are widely applied in practical fields; for example, research topics on fuzzy logic include assessing sustainable alternatives of power generation [96], the assessment of renewable energy systems [110], the assessment of nuclear energy sustainability [111], grid interconnection of renewable energy sources [112], and corporate sustainable performance assessment [113].

The AHP is a multi-criteria decision-making model, and the quantitative analysis method is also a viable multi-criteria decision-making analytic tool. The AHP equation can be used to acquire the relative weights of assessment factors, which is conducive to identifying key influential factors in decision-making problems. In addition to being easy to use and understand, the AHP has practical application value. It can easily be computed using Excel software (to acquire the relative weights of each assessment factor). It is convenient and is applied in numerous fields. The scope of AHP applications includes the following: determining the priority of assessment models, selecting an optimal alternative method, conducting decision-making analysis or risk assessment, determining optimal 
resource allocation, measuring the managerial performance of different fields, analyzing conflict issues and solutions, predicting incident results, and serving as a reference for decision-making support. Research topics on fuzzy logic include the following: the potential survey of photovoltaic power plants [114], analysis on the barriers to renewable energy development [115], the selection of energy efficiency practices in public lighting [116], and assessing water quality in rivers [117].

\subsection{DFuzzy Model Development}

\subsubsection{Validating Criteria for Model Development}

We invited 15 Delphi experts, comprising industry CEOs, public sector employees, and professors, as participants. The initial criteria obtained from the literature review were adopted as a reference for the design of the first questionnaire. After three cycles of the Delphi process, criteria on which the experts reached a consensus on were divided into three dimensions, each of which consisted of three criteria, as follows:

(1) Participation situation: pro-environmental, pattern of subsidies, ratio of subsidy;

(2) Generating capacity: solar home systems, solar photovoltaic parks (solar PV parks), carbon trading;

(3) Storage facilities: private rainwater collection pool (private RWC pool), public rainwater collection pool (public RWC pool), green rainwater infrastructure (GRW infrastructure).

These dimensions and criteria were input through fuzzy logic to construct the DFuzzy model. In addition, the AHP was employed to calculate the relative weight of each criterion. The hierarchical structure provides a systematic overview of the critical risk factors [118].

3.2.2. DFuzzy Model Parameter Definitions and Overview of the Fuzzy Logic Inference System Simulation Algorithm

The variables of the fuzzy logic assessment model could not be automatically generated with the assistance of commercial software, software design, or case studies. Therefore, the DFuzzy model variables had to first be defined for the FLIS to obtain the inference function to compute inference algorithms. The FLIS structure of the DFuzzy model comprises the following: the IF-THEN rule base (inference knowledge base), the fuzzy set for each criterion, the membership function of each criterion, information related to the fuzzy interval, and the FLIS structure of the DFuzzy model (Table 4).

Table 4. Fuzzy logic inference structure of the DFuzzy model.

\begin{tabular}{ccc}
\hline Criteria & Range (Fuzzy Sets) & Output Value \\
\hline Participation situation & 0-100 (\%) & $0-100$ \\
Generating capacity & (Very high, High, Generally, Low, Very low) & Very good $\geq 90$ \\
Storage facilities & (Very much, Much, Average, Little, Very little) & $89 \geq$ Good $\geq 75$ \\
& $0-15$ (Month) & $74 \geq$ Average $\geq 60$ \\
& (Very enough, Just enough, Not enough) & $59 \geq$ Bad $\geq 45$ \\
& (1) $\quad \begin{array}{l}\text { The range can be defined using the default value (0-1) in the } \\
\text { Note }\end{array}$ & MATLAB software; the purpose of defining the fuzzy range was \\
& to facilitate practical applications. & \\
& Membership function: This study employed the commonly used \\
& triangular membership function and Gaussian \\
& membership function. \\
\hline
\end{tabular}

In Table 4, "participation situation" is defined as the degree to which policies to attract resident participation are in place, with the highest participation rate being 100\%. The "Generating capacity" of a household was set as 10 times the household energy consumption. "Storage facilities" indicates the amount of rainwater stored; the maximum value was set as 15 months' consumption. The quantified ranges were defined as the amount required to fulfil daily demand for water and photovoltaic electricity and had 
to exceed the total amount of annual consumption. We employed the commonly used triangular membership function and Gaussian membership function as the membership functions. The quantified output values were defined as between 0 and 100, the scores of which served as a reference in determining the subsidy for the household. The elements comprising each dimension in the fuzzy sets indicate that the participation situation and the generating capacity each comprise five elements, whereas storage facilities consist of three elements. The three main criteria dimensions can be used to created 75 input scenarios $(5 \times 5 \times 3=75)$; these 75 scenarios served as a reference to construct the IF-THEN rule base. After completing the aforementioned procedures, the input scenarios could be inputted into the FLIS of the DFuzzy model to compute the inference algorithm and provide quantified assessment functions. The FLIS data quantification process comprises the following four steps:

(1) Input scenario: The DFuzzy model established by this study can differentiate between 75 types of assessment input data and process input data with imprecise and unclear adjectives. For example, for the variable "participation situation," the scale items "very high, high, generally, low, very low" can serve as precise quantified values or as a hybrid between quantified and qualified input;

(2) Fuzzifier: After inputting scenarios into the FLIS, the data are processed by the Fuzzifier;

(3) Inference engine: After Fuzzifier processing, the processed scenarios are input into the IF-THEN rule base through the inference engine for attribute comparison;

(4) Defuzzifier: After the inference engine completes the rule base comparison, the Defuzzifier process is conducted to establish the corresponding quantified output value for each input scenario.

The parameter definitions of each fuzzy set, membership function, and fuzzy range (for each criterion) were set through the Delphi process. After establishing the IF-THEN rule base, the DFuzzy model has assessment functionality. The data processing center of the DFuzzy model, the FLIS, converts input scenarios into information that is easy to understand and apply. Figure 4 depicts the DFuzzy model scheme. Figure 5 presents the 3D mapping of input criteria and output values. This complex logic inference algorithm is difficult for the human brain to use to categorize the 75 assessment data of each input scenario. Similarly, using conventional mathematical equations to compute data with different computation units and data characteristics is difficult. Because fuzzy logic consists of AI computation functions, it is applicable for processing this unique computation model.

The assessment criteria of the DFuzzy model were participation situation, generating capacity, and storage facilities, which together comprise 75 assessment combinations. Table 4 presents the optimal assessment combination (Very high, Very much, Enough). The DFuzzy model FLIS quantification algorithm indicated that the optimal assessment score of subsidy applications for farm building renovation to facilitate the use of natural resources was 93.4. By contrast, the least favorable score was 21, which required the assessment combination of Very low, Very little, and Not enough. The FLIS computes the 75 assessment combinations and converts each into output values. Again, the FLIS is a scientific computation model that uses logical inference and therefore differs from conventional mathematical computation methods. Figure $5 \mathrm{a}, \mathrm{b}$ presents the 3D mapping of the relationship between the inputs and outputs of the three assessment criteria. 


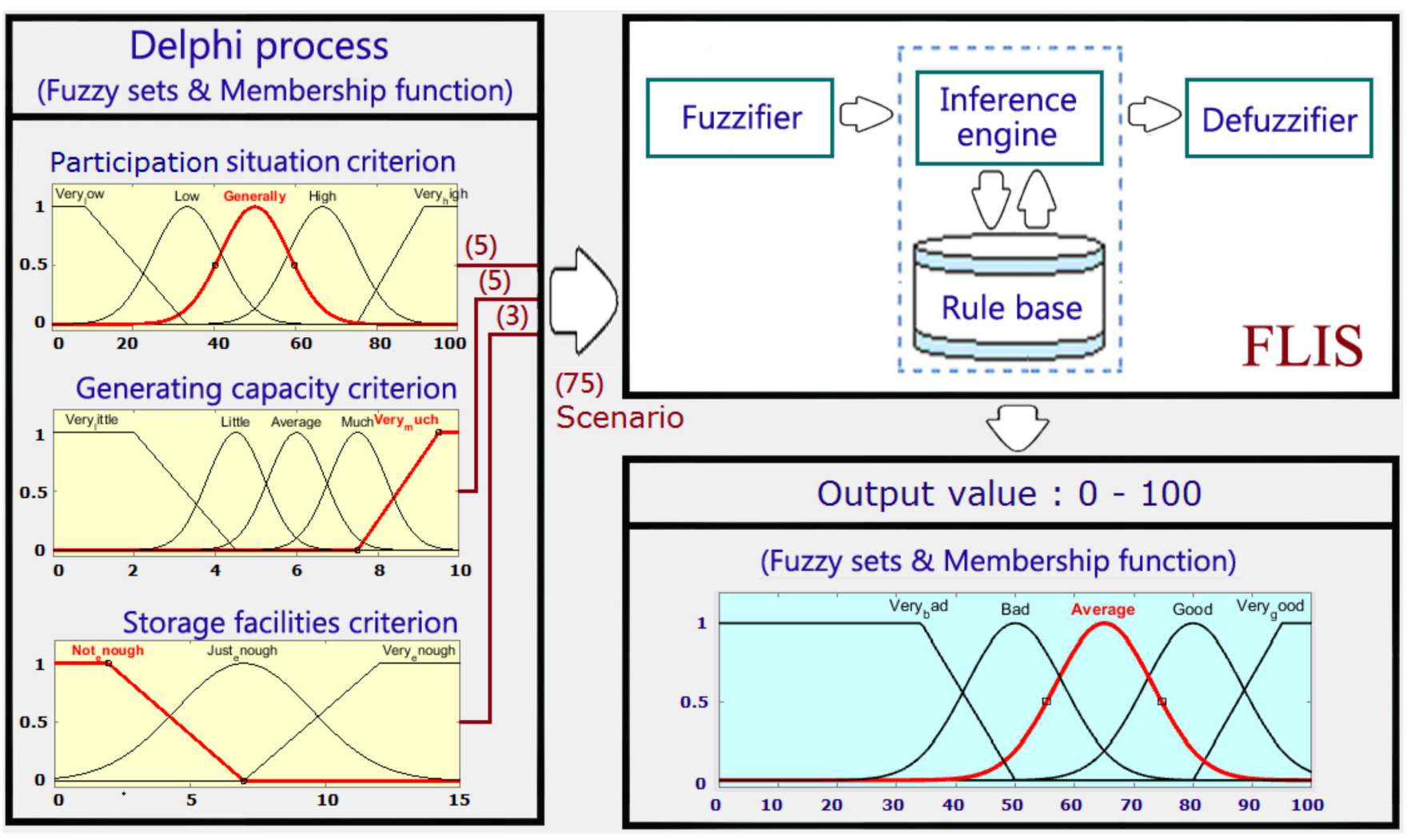

Figure 4. DFuzzy model scheme.
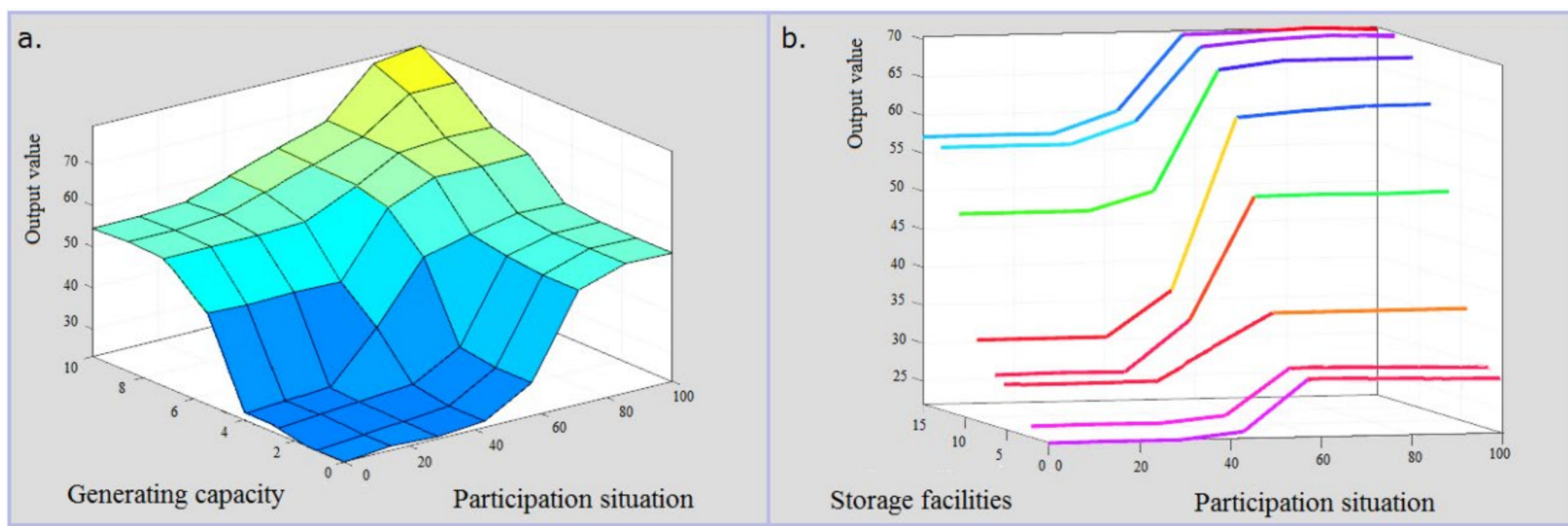

Figure 5. Three-dimensional mapping of input criteria and quantitative output values. ((a) Participation situationGenerating capacity, (b) Participation situation—Storage facilities).

\subsection{DAHP Model Development}

The criteria which the experts reached a consensus on during the Delphi process served as references for the development of the AHP hierarchy and design of AHP-paired comparison questionnaires. Due to the difficulty of selecting option responses in AHP questionnaires, participants commonly responded to the AHP questionnaire initially with options that did not fulfill the AHP consistency verification criteria. This was particularly true for the AHP questionnaire section on rural residents. We delivered 100 AHP questionnaires over 6 months of repeated consultations and acquired 72 sets of questionnaire data that conformed to the AHP consistency verification. The procedure was as follows: 
(1) Using the Delphi process, criteria which experts reached a consensus on were obtained to design the AHP questionnaire;

(2) The AHP paired comparison questionnaire was sent out (or an interview was conducted using it);

(3) AHP consistency verification criteria: (a) the Consistency Index (C.I.) had to be $\leq 0.1$ to satisfy the tolerance deviation value for verification; (b) the Consistency Ratio (C.R.) had to be $\leq 0.1$ (C.R. = C.I. $/$ R.I.). The AHP-paired comparison questionnaire had to fulfill these criteria to be viewed as providing effective investigation data. R.I. refers to random index and was obtained from a random index table;

(4) The questionnaires were retrieved and compiled. Questionnaire data that did not conform to AHP-consistent verification were excluded;

(5) The paired comparison matrix (dual matrix) for assessment factors were established to compute the relative weight of each assessment factor, which served as a reference for decision-making assessment and application.

Following this procedure, we established Level 1 dimensions and computed the relative weighting of each criterion in Level 2 dimensions, as listed in Tables 5-8. Table 9 compiles the relative weighting and sequence of each criterion.

Table 5. (Level 1).

\begin{tabular}{cccc}
\hline A/B & Participation Situation & Generating Capacity & Storage Facilities \\
\hline Participation situation & 1 & $11 / 2$ & $11 / 2$ \\
\hline Generating capacity & $2 / 3$ & 1 & 2 \\
\hline Storage facilities & $2 / 3$ & $1 / 2$ & 1 \\
\hline Weighting value & 0.42 & 0.35 & 0.22 \\
\hline Remark & & C.I. $=0.0268$; R.I. $=0.58 ;$ C.R. $=0.0462$ \\
\hline
\end{tabular}

Table 6. (Level 2-1).

\begin{tabular}{cccc}
\hline A/B & Pro-Environmental & Pattern of Subsidies & Ratio of Subsidy \\
\hline Pro-Environmental & 1 & 2 & $4 / 5$ \\
\hline Pattern of subsidies & $1 / 2$ & 1 & $2 / 5$ \\
\hline Ratio of subsidy & $11 / 4$ & $21 / 2$ & 1 \\
\hline Weighting value & 0.36 & 0.18 & 0.45 \\
\hline Remark & & C.I. $=$ 0; R.I. $=0.58 ;$ C.R. $=0$ & \\
\hline
\end{tabular}

Table 7. (Level 2-2).

\begin{tabular}{cccc}
\hline A/B & Solar Home Systems & Solar PV Parks & Carbon Trading \\
\hline Solar home systems & 1 & $3 / 5$ & $1 / 5$ \\
\hline Solar PV parks & $12 / 3$ & 1 & $1 / 2$ \\
\hline Carbon trading & 5 & 2 & 1 \\
\hline Weighting value & 0.14 & 0.26 & 0.60 \\
\hline Remark & & C.I. $=0.0092 ;$ R.I. $=0.58 ;$ C.R. $=0.0159$ & \\
\hline
\end{tabular}


Table 8. (Level 2-3).

\begin{tabular}{cccc}
\hline A/B & Private RWC Pool & Public RWC Pool & GRW Infrastructure \\
\hline Private RWC pool & 1 & $1 / 5$ & $1 / 2$ \\
\hline Public RWC pool & 5 & 1 & $11 / 2$ \\
\hline GRW infrastructure & 2 & $2 / 3$ & 1 \\
\hline Weighting value & 0.13 & 0.55 & 0.31 \\
\hline Remark & & C.I. $=0.0146$; R.I. $=0.58 ;$ C.R. $=0.0252$ & \\
\hline
\end{tabular}

Table 9. Compilation of relative weight and sequence of each criterion.

\begin{tabular}{|c|c|c|c|}
\hline Criteria (Level 1): $\omega_{i}$ & Criteria (Level 2): $\omega_{i}$ & $($ Level $1 \times 2) \omega_{i}$ & Seq. \\
\hline \multirow{3}{*}{$\begin{array}{l}\text { Participation situation } \\
\qquad(1-1): 0.42\end{array}$} & $\begin{array}{l}\text { Pro-Environmental } \\
\text { (2-1-1): } 0.36\end{array}$ & 0.15 & 3 \\
\hline & $\begin{array}{l}\text { Pattern of subsidies } \\
\qquad(2-1-2): 0.18\end{array}$ & 0.08 & 6 \\
\hline & $\begin{array}{l}\text { Ratio of subsidy } \\
\quad(2-1-3): 0.45\end{array}$ & 0.20 & 2 \\
\hline \multirow{3}{*}{$\begin{array}{l}\text { Generating capacity } \\
(1-2): 0.35\end{array}$} & $\begin{array}{l}\text { Solar home systems } \\
(2-2-1): 0.14\end{array}$ & 0.05 & 8 \\
\hline & $\begin{array}{l}\text { Solar PV parks } \\
\text { (2-2-2): } 0.26\end{array}$ & 0.09 & 5 \\
\hline & $\begin{array}{l}\text { Carbon trading } \\
(2-2-3): 0.60\end{array}$ & 0.21 & 1 \\
\hline \multirow{3}{*}{$\begin{array}{l}\text { Storage facilities } \\
\quad(1-3): 0.22\end{array}$} & $\begin{array}{l}\text { Private RWC pool } \\
\quad(2-3-1): 0.13\end{array}$ & 0.03 & 9 \\
\hline & $\begin{array}{l}\text { Public RWC pool } \\
\text { (2-3-2): } 0.55\end{array}$ & 0.12 & 4 \\
\hline & $\begin{array}{c}\text { GRW infrastructure } \\
(2-3-3): 0.31\end{array}$ & 0.07 & 7 \\
\hline Total weighting value & & 1.00 & \\
\hline
\end{tabular}

As Table 9 indicates, the relative weights of the dimensions in descending order were participation situation, generating capacity, and storage facilities. The assessment factors with the highest relative weights in Level 2, in descending order, were carbon trading (0.21), ratio of subsidy (0.20), pro-environmental (0.15), public RWC pool (0.12), and solar photovoltaic parks (0.09).

\subsection{DFAHP Model Development and Application}

This section describes the development and application of the DFAHP model. Figure 6 illustrates the development process and the assessment application of the model, which may be described as follows:

(1) Development: The DFAHP model was developed by combining the features of the Delphi model (e.g., criteria confirmed suitable for model development by experts), the DFuzzy model (e.g., fuzzy sets, fuzzy scale, suitable membership functions, and the rule base), and the DAHP model (e.g., AHP hierarchy, criteria weights, and computation protocols). The purpose of the DFAHP model was to provide a convenient decision-making analysis;

(2) Application: First, the Delphi-Fuzzy process was employed to analyze practical cases; the assessment combination was confirmed and inputted into the FLIS to acquire a quantitative output algorithm. Subsequently, the Delphi-AHP process was conducted 
to complete AHP questionnaires and to compute the relative weight of each criterion. Finally, the DFAHP model was applied to compute the quantified assessment value of each criterion: $f\left(y_{s}\right)=f\left(x_{s}\right) \times\left(\Sigma \omega_{i}\right)$. The results were to be used as a judgment factor and a reference for decision making.

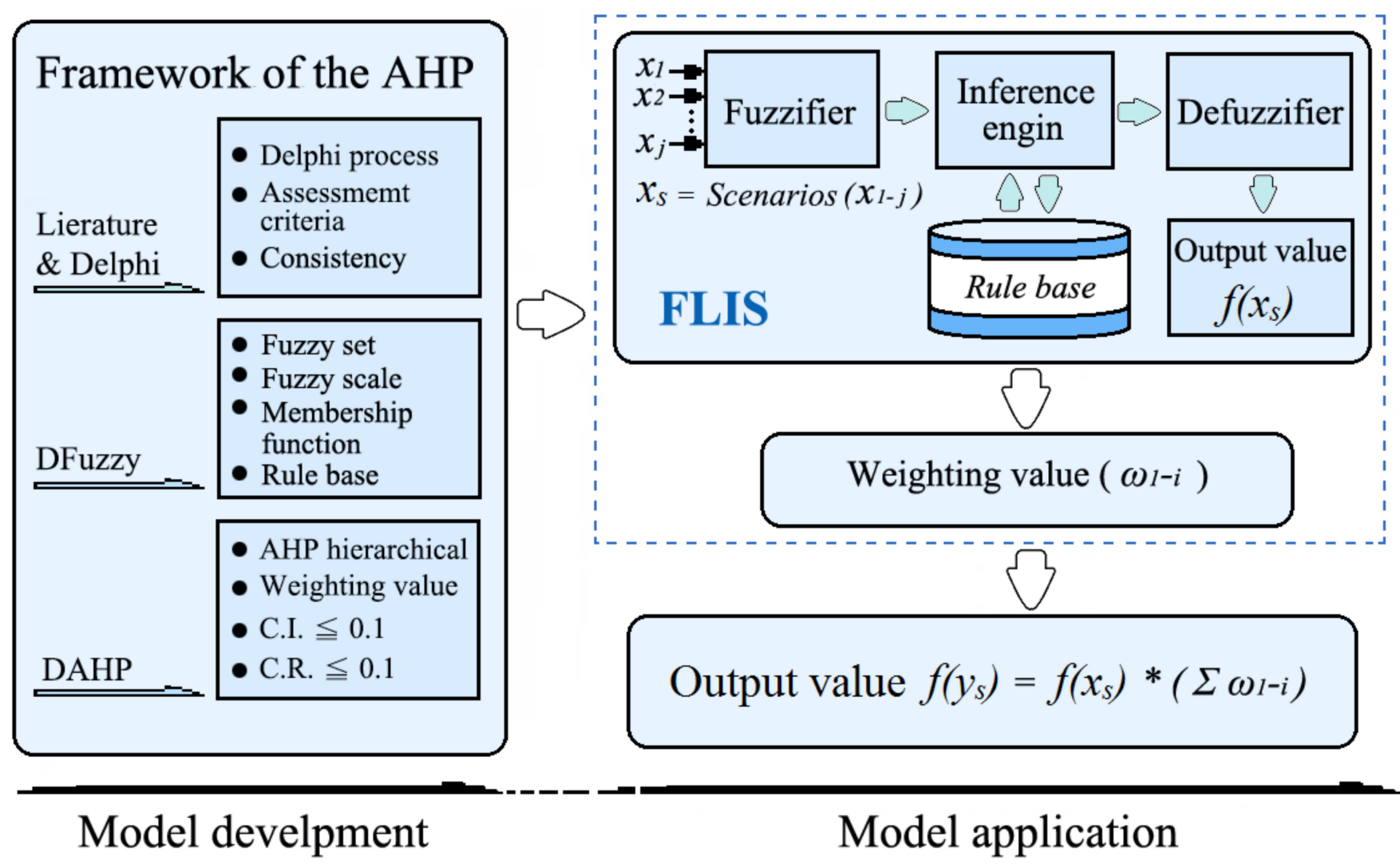

Figure 6. Development process and assessment application of the DFAHP model.

\section{Case Study}

This study used a rural building in Wenquan Township, Conghua District, Guangdong Province as an example. After conducting a 3D construction simulation, we employed the DFAHP model for decision-making assessment to detail how policies that provide renovation subsidies for rural buildings with wide areas are conducive to the development of sustainable sunlight energy and rainwater use.

\subsection{Summary of Case 1 and Case 2}

Wenquan is a prosperous township in the Guangdong-Hong Kong-Macao Greater Bay Area. In addition to its renowned hot springs tourist attractions, the township is a famous ecological showcase area. Conghua District spans $1974.5 \mathrm{~km}^{2}$ and has a population of approximately 642,100; the district has the lowest permanent population and urbanization rate (approximately 45.01\%) in the province. Nonetheless, Wenquan features diverse development features, including its tourism industry, tourism products, farm-oriented restaurants, and ecological farms. In addition to serving as the major leisure tourism attraction for Guangzhou City on weekends, these features spur economic activity in Wenquan and allow farmers to have various sources of income, thus reducing their dependency on agriculture. Furthermore, due to an aging farmer population, agricultural products yielding unfavorable financial returns, and the next generation exhibiting little willingness to inherit their parents' careers in agricultural production, vast tracts of farmland now lie fallow, and some farmers are even seeking to rent their farmland. Because Wenquan has high annual average sunlight hours and abundant rainfall, this study proposed that 
policies that provide subsidies for rural buildings to use sustainable resources can generate value-adding effects for fallow farmland and household property. In addition, these subsidies may be beneficial for the vitalization of Wenquan and can promote the development of Wenquan into a showcase township with low carbon emissions.

Figure 7 is a conceptual diagram of the relative positions of existing rural buildings and renovation areas to enable the buildings to use sustainable resources for Case 1. Figure 8 depicts the right-side view, a 3D diagram, and the layout of the overall simulated construction for Case 2. The rural building in Case 1 is a common luxurious villa in a prosperous coastal rural township. Because many living in southern China value the relationship between housing structure and feng shui, large water pools are common in rural areas. In addition to their feng shui connotations, the pools provide flood prevention, tourism, and irrigation functions and are deeply valued by rural citizens.

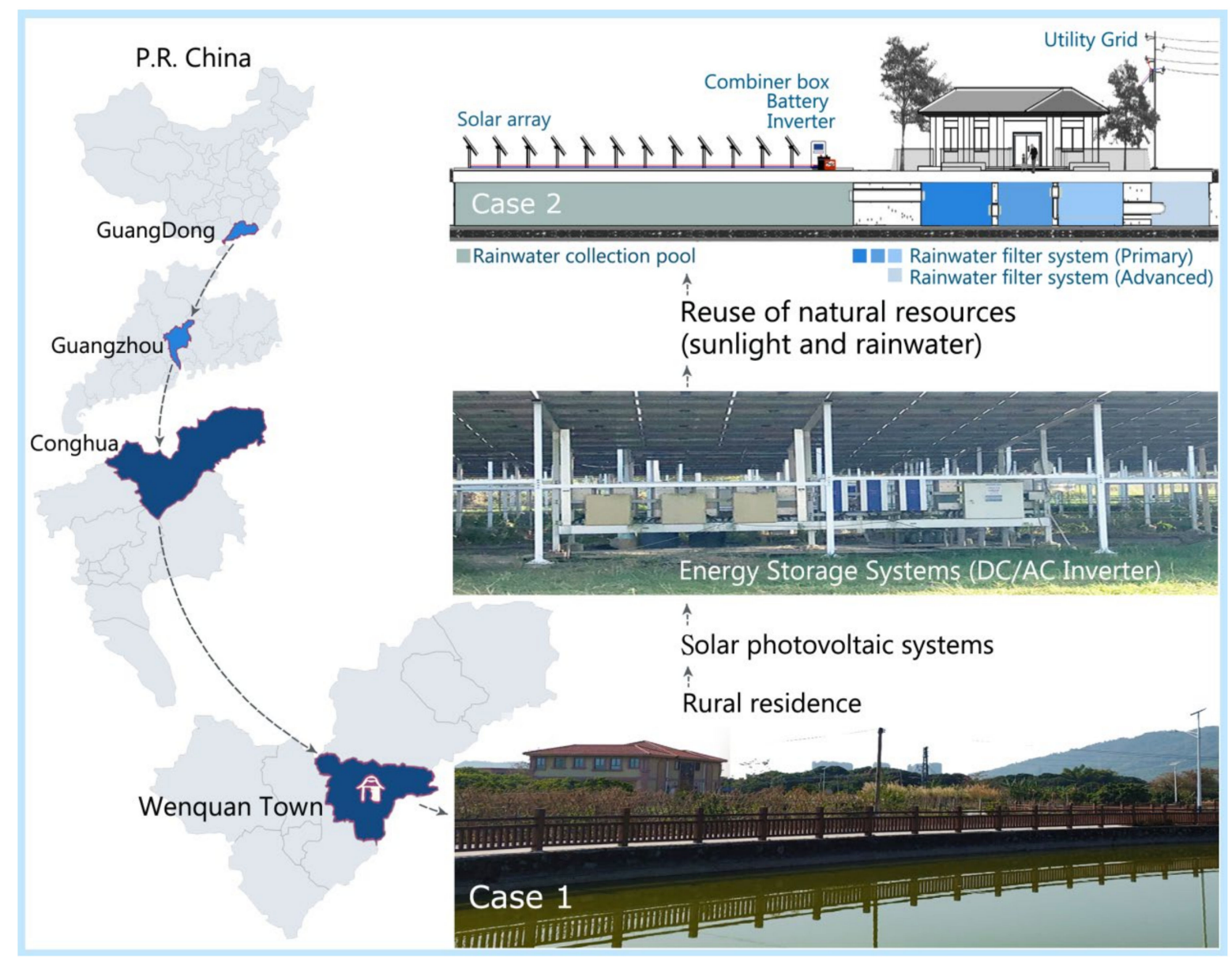

Figure 7. Conceptual diagram of the location and construction.

Figure 8 displays the simulated construction of Case 2. We assumed that the buildings house families of three. The typical farming area in rural areas is $1-5 \mathrm{mu}$ (the actual farming area of individuals is reported by provinces or cities). One mu equals $660 \mathrm{~m}^{2}$ of land. For the computation convenience of the DFAHP model, we assumed that the average farming area of each citizen was $1 \mathrm{mu}$. Therefore, a family of three would own $3 \mathrm{mu}$ or $1980 \mathrm{~m}^{2}$ of land. Although most agricultural land is not connected with residential land, the right of farmers in China to own farmland is established on the basis of fairness. This results in a fair division of land and facilitates joint development, which is conducive to implementing policies on using sustainable resources in rural China. The renovation concept of rural residences in Case 2 originated from the large rural villa in Case 1. Figure 8c depicts the construction layout of Case 2. The renovation plan was as follows: 
(1) The total area for the solar home system was $660 \mathrm{~m}^{2}$. Each $10 \mathrm{~m}^{2}$ contained solar panels generating $1 \mathrm{~kW}$. After excluding $60 \mathrm{~m}^{2}$ of the area for facility requirements, the $660 \mathrm{~m}^{2}$ area generated $60 \mathrm{~kW}$. The total electricity output of the solar system was computed using the average annual sunlight hours (1690.2 h), which approximates 4.63 daily sunlight hours. Based on a $65 \%$ sunshine efficiency, the daily output of the system was approximately $60 \mathrm{~kW} \times(4.63 \mathrm{~h} /$ day $\times 65 \%)=180.6 \mathrm{kWh} /$ day. Therefore, the total monthly output of the system was $5418 \mathrm{kWh} /$ month $(180.6 \mathrm{kWh} /$ day $\times 30$ days /month). The average monthly power use of a typical families ranges from 200 to $400 \mathrm{kWh}$ (the range is influenced by seasonal variations). Accordingly, the average monthly surplus energy exceeds $5000 \mathrm{kWh} /$ month. Figure $8 \mathrm{c}(1)$ and (2) depict the solar array and relevant equipment.

(2) The total rainwater collection area was approximately $900 \mathrm{~m}^{2}$. The pool depth was $1.8 \mathrm{~m}$. After excluding space for the primary and advanced rainwater filter system and setting the pool depth at $1.5 \mathrm{~m}$ for calculation, the effective water storage volume exceeds $1350 \mathrm{~m}^{3}\left(900 \mathrm{~m}^{2} \times 1.5 \mathrm{~m}\right)$. Figure $8 \mathrm{c}(3)$, (4), and (5) depict the infrastructure. On the basis that average water consumption per capita is approximately $250 \mathrm{~L}$, the daily and monthly water consumption of a family of three is $750 \mathrm{~L}$ and $22,500 \mathrm{~L}$ (22.5 metric tons), respectively. This amounts to an annual water consumption of $270 \mathrm{~m}^{3}$. The average annual rainfall of coastal regions in southern China is $1652.5 \mathrm{~mm}$, which does not include the abundant rainfall brought by unpredicted typhoons. The infrastructure depicted in Figure 8c would reach maximum capacity numerous times each year, with $1000 \mathrm{~m}^{3}$ of surplus rainwater accumulated annually.

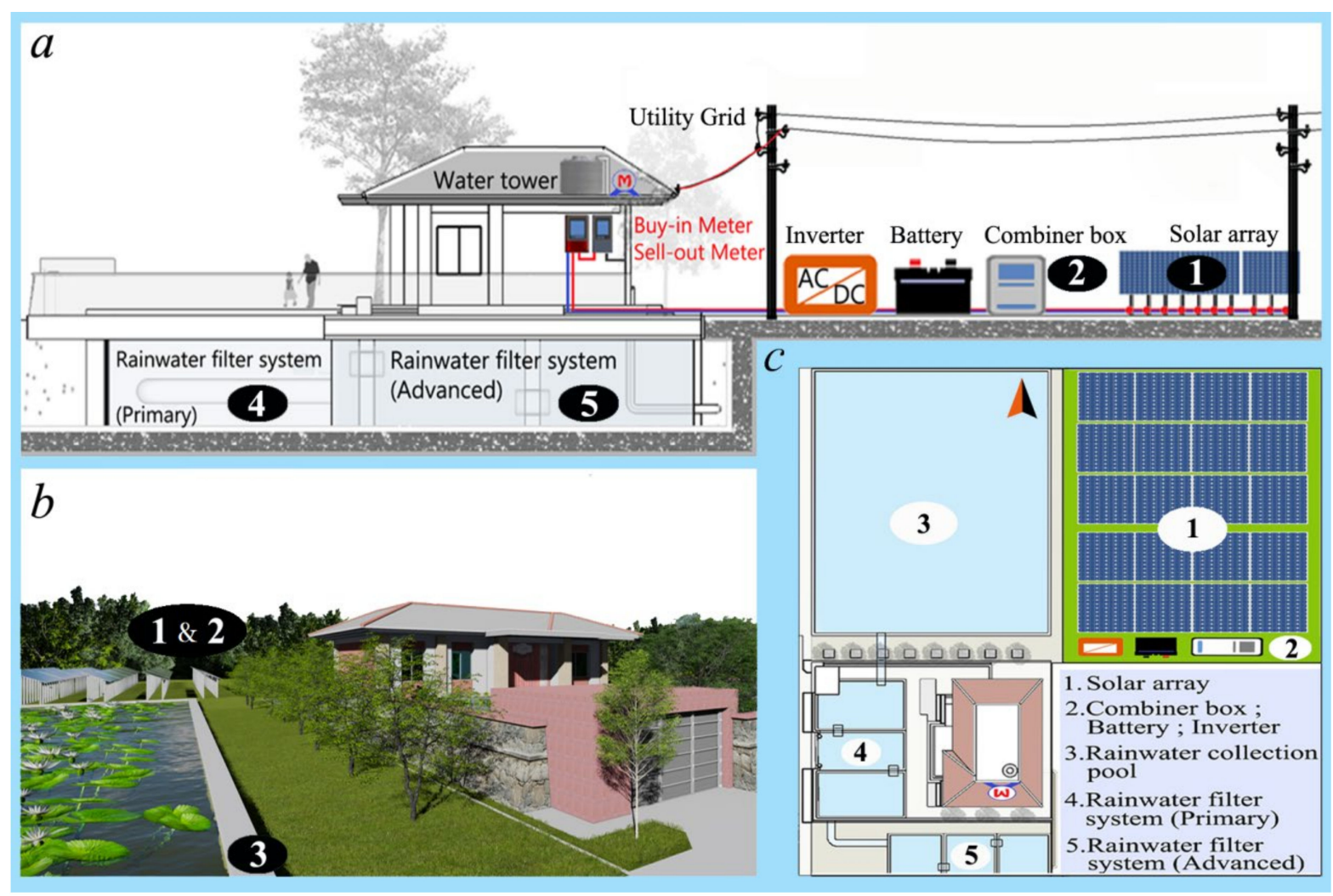

Figure 8. Simulated construction for Case 2 ((a) right side view, (b) 3D diagram, (c) layout).

\subsection{DFAHP Model Quantitative Assessment and Analysis of Cases}

Figure 7 (Case 1) and Figure 8 (Case 2) illustrate the surrounding environments of the residences. By using the Delphi process, the assessment combinations were acquired as follows: 
(1) Surrounding environment for Case 1 building: The surrounding environment consists of a large public rainwater collection pool, solar water heater, and solar streetlamps. A large area of idle farmland sits next to the residence.

(2) Surrounding environment for the construction simulation of Case 2: The environment consists of a solar home system and rainwater infrastructure installed in an empty space beside the residence in Case 1.

(3) Using the Delphi process, the assessment combination of Case 1 was set as follows: Participation situation: Very high; Generating capacity: Very little; Storage facilities: Just enough). The assessment combination of Case 2 was set as follows: Participation situation: Very high; Generating capacity: Very much; Storage facilities: Very enough).

(4) In the DFAHP model, the overall assessment of the quantified output values of Case 1 and Case 2 were computed using $f\left(x_{s}\right)$. Subsequently, $f\left(y_{s}\right)=f\left(x_{s}\right) \times W_{i}$ was computed to obtain the value relationship of each criterion (Table 10).

(5) Figure 9 displays a comparison of the overall assessments of the quantified output values of the cases.

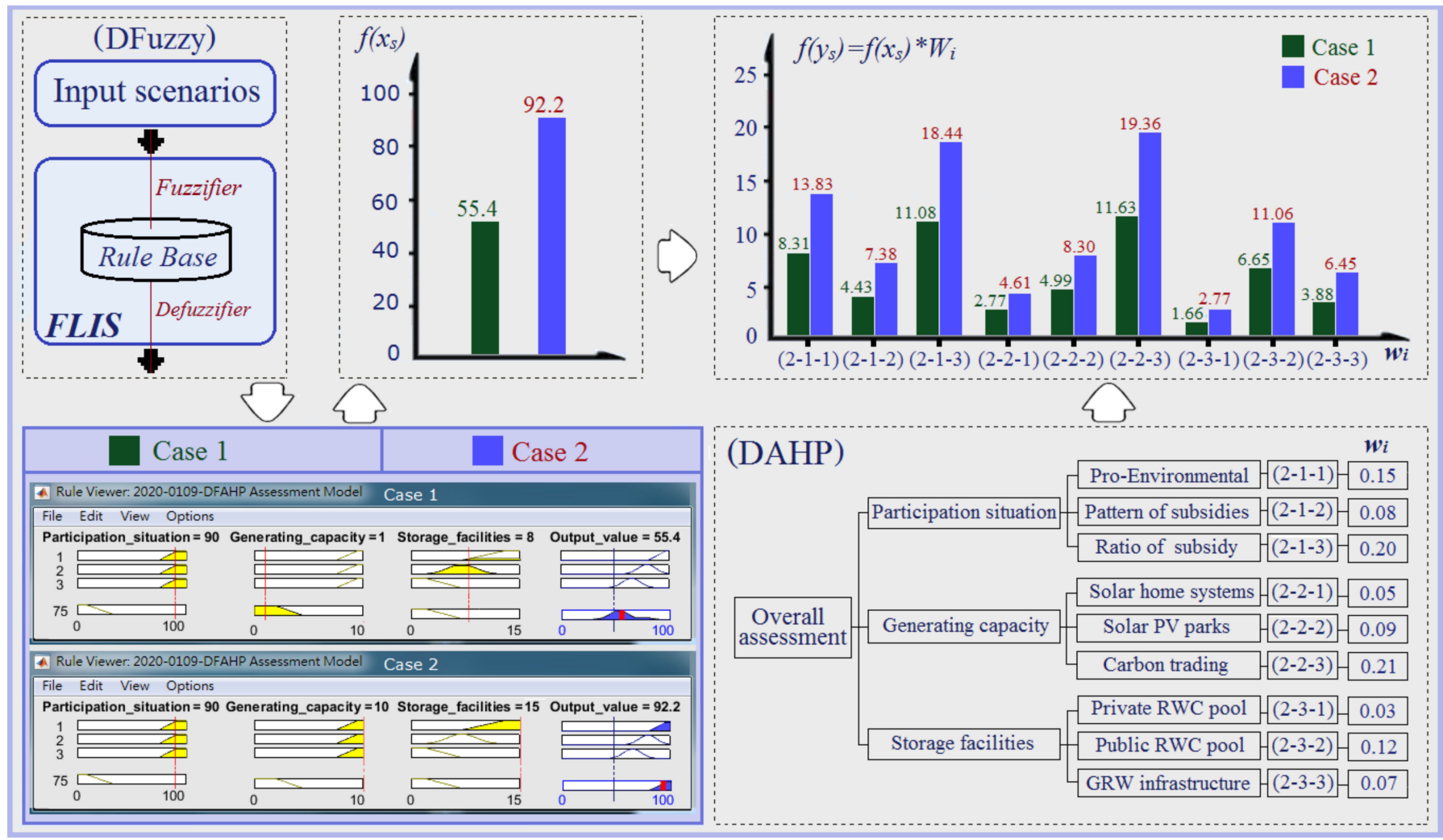

Figure 9. Comparison of the overall assessments of the quantified output values of Case 1 and Case 2.

Table 10. DFAHP assessment of the quantified output values of Case 1 and Case 2.

\begin{tabular}{|c|c|c|c|c|c|c|}
\hline \multirow{2}{*}{ Criteria } & \multicolumn{2}{|c|}{ Scenarios $f\left(x_{s}\right)$} & \multirow{2}{*}{\multicolumn{2}{|c|}{$W_{i}$}} & \multicolumn{2}{|c|}{$f\left(y_{s}\right)=f\left(x_{s}\right) \times W_{i}$} \\
\hline & Case 1 & Case 2 & & & Case 1 & Case 2 \\
\hline \multirow{3}{*}{ Participation situation } & \multirow{3}{*}{ Very high } & \multirow{3}{*}{ Very high } & $(2-1-1)$ & 0.15 & 8.31 & 13.83 \\
\hline & & & $(2-1-2)$ & 0.08 & 4.43 & 7.38 \\
\hline & & & $(2-1-3)$ & 0.20 & 11.08 & 18.44 \\
\hline \multirow{3}{*}{ Generating capacity } & \multirow{3}{*}{ Very little } & \multirow{3}{*}{ Very much } & $(2-2-1)$ & 0.05 & 2.77 & 4.61 \\
\hline & & & $(2-2-2)$ & 0.09 & 4.99 & 8.30 \\
\hline & & & $(2-2-3)$ & 0.21 & 11.63 & 19.36 \\
\hline
\end{tabular}


Table 10. Cont.

\begin{tabular}{|c|c|c|c|c|c|c|}
\hline \multirow{2}{*}{ Criteria } & \multicolumn{2}{|c|}{ Scenarios $f\left(x_{s}\right)$} & \multirow{2}{*}{\multicolumn{2}{|c|}{$W_{i}$}} & \multicolumn{2}{|c|}{$f\left(y_{s}\right)=f\left(x_{s}\right) \times W_{i}$} \\
\hline & Case 1 & Case 2 & & & Case 1 & Case 2 \\
\hline \multirow{3}{*}{ Storage facilities } & \multirow{3}{*}{ Just enough } & \multirow{3}{*}{ Very enough } & $(2-3-1)$ & 0.03 & 1.66 & 2.77 \\
\hline & & & $(2-3-2)$ & 0.12 & 6.65 & 11.06 \\
\hline & & & $(2-3-3)$ & 0.07 & 3.88 & 6.45 \\
\hline Output value & 55.4 & 92.2 & Total & 1.00 & 55.4 & 92.2 \\
\hline
\end{tabular}

The DFAHP model assessment of Case 1 revealed a total output value of 55.4, which was unsatisfactory. However, Case 2 had a total output value of 92.2, which achieved the subsidy conditions for rural building renovation for solar power generation and the collection and use of rainwater. The quantified output values of each criterion in Level 2 in descending order were as follows: (2-2-3) carbon trading (19.36), (2-1-3) ratio of subsidy (18.44), (2-1-1) pro-environmental (13.83), (2-3-2) public RWC pool (11.06), and (2-2-2) solar photovoltaic installation (8.30). Case 2 highlighted carbon trading as the main concern of rural citizen participation in the reconstruction or renovation of residential buildings. This indicates that rural dwellers favor long-term acquisition of surplus water and electricity and prefer to obtain long-term carbon-reduction incentives for each $\mathrm{kWh}$ of electricity or metric ton of water. In addition, the subsidy percentage is a key focus of rural residents.

\section{Conclusions and Suggestions}

The use of renewable energy is a primary concern of sustainable development. $\mathrm{CO}_{2}$ emissions have resulted in disasters caused by abnormal climate changes. Livelihoods in certain regions have been severely affected by food and water shortages. Countries should establish both incentives and strict environmental protection regulations as well as economic development policies that prioritize the environment and encourage industry and public participation in environmental protection activities. Through this approach, global $\mathrm{CO}_{2}$ emissions can be inhibited, and severe climate change crises can be mitigated. In recent years, China has strictly monitored pollution by every industry and has exerted environmental governance in rural areas. Regional governments have established solar power generation subsidy policies for households, manufacturers, schools, agriculture, fisheries, livestock industries, and various other industries. This study proposed a model conducive to sustainable natural resource use in rural areas and revealed participation conditions as expectations for policies regarding the long-term acquisition of surplus water and electricity and incentives for energy conservation and carbon reduction. The results can serve as a reference for implementing relevant policies.

The proposed AI-MCDM model can convert complex challenges regarding government policy on subsidies into easy-to-understand quantitative values for comparison with the following advantages:

(1) The model comprises easy-to-understand and easy-to-accept scientific computation functions. It has high degrees of objectivity, fairness, and adaptivity.

(2) According to the case study, every rural household can generate $5000 \mathrm{kWh}$ of surplus electricity monthly and over $1000 \mathrm{~m}^{3}$ of surplus rainwater for distribution. Accordingly, Guangdong Province, which has approximately 105,700 rural households, can generate a considerable amount of regional energy.

(3) The transparency of the model encourages resident participation in public policies, which is conducive to policy implementation.

(4) In addition to serving as a reference for decision making for policy management, the model enables residents to conduct self-evaluations to identify relevant factors that subsidy policies should focus on.

Based on the findings, suggestions to support rural townships with advantageous sunlight and water resources in developing sustainable resource use are as follows: 
(1) Food crises, a serious concern, has garnered attention from countries around the world and prompted them to strictly monitor land use and stipulate that specific land be used for agriculture. Consequentially, holders of smaller properties and rural residents who do not possess farming capabilities generally rent or retire farmland; thus, these strict regulations have resulted in farmland losing its diverse use value.

(2) Existing studies have focused on sustainable development for urban areas. Sustainable development in spacious rural areas, despite being a field worthy of discussion, is often ignored.

(3) Water and electricity are key factors for crops. In addition, water resources and electricity generation are crucial sustainable energy topics that have garnered global attention. The model proposed in this study can provide positive, practical contributions to energy conservation and carbon emissions throughout the world, enable the flexible use of retired and idle farmland, and promote the implementation of low-carbon lifestyles to develop characteristic rural towns.

(4) Wenquan Township, which is situated on mountainous terrain, receives abundant sunshine and has rich water resources. The region is a prosperous rural area; therefore, it contains idle farmland. Policy goals in Wenquan focus on the development of cultural, tourism, ecological, and agricultural industries. Wenquan is a national-level characteristic township that emphasizes ecological characteristics. Policies that allow for the flexible use of farmland and reward sustainable energy development are conducive to the characteristic development of this ecological township.

(5) The AI-MCDM model established in this study can serve as a reference for formulating new polices and provide support in decision making.

Author Contributions: Conceptualization, S.-L.H. and M.-R.Y.; Funding acquisition, S.-L.H. and Y.F.; Investigation, S.-L.H., Y.F., Y.S., R.J. and M.-R.Y.; Methodology, S.-L.H. and M.-R.Y.; Project administration, S.-L.H., Y.F. and R.J.; Resources, Y.F. and Y.S.; Supervision, Y.F. and M.-R.Y.; Writing-original draft, S.-L.H. and Y.S.; Writing—review \& editing, Y.F., R.J. and M.-R.Y. All authors have read and agreed to the published version of the manuscript.

Funding: This research was funded by Nanfang College and iiLABs.

Institutional Review Board Statement: Not applicable.

Informed Consent Statement: Not applicable.

Data Availability Statement: The data supporting the reported results in the present study will be available on request from the corresponding author or the first author.

Conflicts of Interest: The authors declare no conflict of interest.

\section{References}

1. Hsueh, S.L. Assessing the effectiveness of community-promoted environmental protection policy by using a Delphi-fuzzy method: A case study on solar power and plain afforestation in Taiwan. Renew. Sustain. Energy Rev. 2015, 49, 1286-1295. [CrossRef]

2. Hsueh, S.L.; Liu, J.; Lin, C. Influence of Environmental Atmosphere on Tourists' Perceived Value and Willingness to Revisit. J. Environ. Prot. Ecol. 2019, 20 (Special A), 84-91.

3. IPCC. Special Report: Global Warming of $1.5^{\circ}$ C. IPCC. 2019. Available online: http://www.ipcc.ch/report/sr15/ (accessed on 22 September 2021).

4. Leng, G. Keeping global warming within $1.5^{\circ} \mathrm{C}$ reduces future risk of yield loss in the United States: A probabilistic modeling approach. Sci. Total Environ. 2018, 644, 52-59. [CrossRef] [PubMed]

5. Xiao, X.J.; Jiang, K.J. China's nuclear power under the global $1.5^{\circ} \mathrm{C}$ target: Preliminary feasibility study and prospects. Adv. Clim. Chang. Res. 2018, 9, 138-143. [CrossRef]

6. Lwasa, S.; Buyana, K.; Kasaija, P.; Mutyaba, J. Scenarios for adaptation and mitigation in urban Africa under $1.5^{\circ} \mathrm{C}$ global warming. Curr. Opin. Environ. Sustain. 2018, 30, 52-58. [CrossRef]

7. Gaupp, F.; Hall, J.; Mitchell, D.; Dadson, S. Increasing risks of multiple breadbasket failure under 1.5 and $2{ }^{\circ} \mathrm{C}$ global warming. Agric. Syst. 2019, 175, 34-45. [CrossRef]

8. Singh, R.; Kumar, R. Climate versus demographic controls on water availability across India at $1.5^{\circ} \mathrm{C}, 2.0^{\circ} \mathrm{C}$ and $3.0^{\circ} \mathrm{C}$ global warming levels. Glob. Planet. Chang. 2019, 177, 1-9. [CrossRef] 
9. Ma, X.; Zhao, C.; Tao, H.; Zhu, J.; Kundzewicz, Z.W. Projections of actual evapotranspiration under the $1.5^{\circ} \mathrm{C}$ and $2.0^{\circ} \mathrm{C}$ global warming scenarios in sandy areas in northern China. Sci. Total Environ. 2018, 645, 1496-1508. [CrossRef] [PubMed]

10. Gao, B.; Ju, X.; Meng, Q.; Cui, Z.; Christie, P.; Chen, X.; Zhang, F. The impact of alternative cropping systems on global warming potential, grain yield and groundwater use. Agric. Ecosyst. Environ. 2015, 203, 46-54. [CrossRef]

11. Carvalho, K.S.; Wang, S. Characterizing the Indian Ocean sea level changes and potential coastal flooding impacts under global warming. J. Hydrol. 2019, 569, 373-386. [CrossRef]

12. Carlson, A.E.; Dutton, A.; Long, A.J.; Milne, G.A. PALeo constraints on SEA level rise (PALSEA): Ice-sheet and sea-level responses to past climate warming. Quat. Sci. Rev. 2019, 212, 28-32. [CrossRef]

13. Koutroulis, A.G. Dryland changes under different levels of global warming. Sci. Total Environ. 2019, 655, 482-511. [CrossRef]

14. Prăvălie, R. Major perturbations in the Earth's forest ecosystems. Possible implications for global warming. Earth Sci. Rev. 2018, 185, 544-571. [CrossRef]

15. Silva, P.S.; Bastos, A.; Libonati, R.; Rodrigues, J.A.; DaCamara, C.C. Impacts of the $1.5^{\circ} \mathrm{C}$ global warming target on future burned area in the Brazilian Cerrado. Forest Ecol. Manag. 2019, 446, 193-203. [CrossRef]

16. Wu, F.; Geng, Y.; Tian, X.; Zhong, S.; Wu, W.; Yu, S.; Xiao, S. Responding climate change: A bibliometric review on urban environmental governance. J. Clean. Prod. 2018, 204, 344-354. [CrossRef]

17. Han, G.G.; Liu, X.Y.; Song, L.; Han, Z.Y.; Su, Y.; Du, X.Y.; Tsai, M. Estimation of carbon dioxide emissions in China by 2030. Elect. Power Technol. Environ. Protect. 2013, 29, 1-3.

18. Baike, Baidu, 2018 21st Conference of the Parties. 2019. Available online: https://baike.baidu.com/item/\%E7\%AC \%AC2 1\%E5\%B1\%8A\%E8\%81\%94\%E5\%90\%88\%E5\%9B\%BD\%E6\%B0\%94\%E5\%80\%99\%E5\%8F\%98\%E5\%8C\%96\%E5\%A4\%A7\%E4 \%BC\%9A/18862811?fromtitle=\%E5\%B7\%B4\%E9\%BB\%8E\%E6\%B0\%94\%E5\%80\%99\%E5\%8F\%98\%E5\%8C\%96\%E5\%A4\%A7 $\%$ E4\%BC\%9A\&fromid=18895877\&fr=aladdin (accessed on 22 September 2021).

19. China Network Television. 2019 Climate Change Conference President: China Has a Key Effect on Climate Change. 2019. Available online: http://big5.taiwan.cn/xwzx/PoliticsNews/201912/t20191205_12223265.htm (accessed on 22 September 2021).

20. Zhang, C.; Cui, C.; Zhang, Y.; Yuan, J.; Luo, Y.; Gang, W. A review of renewable energy assessment methods in green building and green neighborhood rating systems. Energy Build. 2019, 195, 68-81. [CrossRef]

21. Zhu, F.; Zhong, P.; Cao, Q.; Chen, J.; Sun, Y.; Fu, J. A stochastic multi-criteria decision making framework for robust water resources management under uncertainty. J. Hydrol. 2019, 576, 287-298. [CrossRef]

22. Long, H.; Lin, B.; Ou, Y.; Chen, Q. Spatio-temporal analysis of driving factors of water resources consumption in China. Sci. Total Environ. 2019, 690, 1321-1330. [CrossRef]

23. Sun, L.; Pan, B.; Gu, A.; Lu, H.; Wang, W. Energy-water nexus analysis in the Beijing-Tianjin-Hebei region: Case of electricity sector. Renew. Sustain. Energy Rev. 2018, 93, 27-34. [CrossRef]

24. Omer, A.M. Water resources and freshwater ecosystems in Sudan. Renew. Sustain. Energy Rev. 2008, 12, 2066-2091. [CrossRef]

25. Hsueh, S.L.; Sun, Y.; Yan, M.R. Conceptualization and Development of a DFuzzy Model for Low-Carbon Ecocieies. Sustainability 2019, 11, 5833. [CrossRef]

26. Conghua Information Website, Population Scale and Distribution of Guangzhou Province in 2018, Guangzhou Statistics Bureau. 2019. Available online: http:/ / kuaibao.qq.com/s/20190218A0SET600?refer=spider (accessed on 22 September 2021).

27. Guangzhou Province Conghua People's Government 2019. Communique of the Third National Agricultural Census (Conghua; First report). 2018. Available online: http:/ / www.conghua.gov.cn/zwgk/sjfb/tjgb/content/post_3166313.html (accessed on 22 September 2021).

28. Climate Change Bulletin, 2019. Average sunshine hours in Guangzhou Province. 2019. Available online: http:/ /www.sohu.com/ a/291548398_803681 (accessed on 22 September 2021).

29. Guangzhou Province Conghua Meteorological Bureau, 2019 White Paper of the Conghua District Meteorological Public Service. 2019. Available online: http:/ / www.conghua.gov.cn/zgch/fwgk/201903/da31e9081f2142d79e2d671d4b6be4da/files/820db1 cbe91448908999ec5c94e3bdb9.pd (accessed on 22 September 2021).

30. Taniguchi, K. Future changes in precipitation and water resources for Kanto Region in Japan after application of pseudo global warming method and dynamical downscaling. J. Hydrol. Reg. Stud. 2016, 8, 287-303. [CrossRef]

31. Kojiri, T.; Hamaguchi, T.; Ode, M. Assessment of global warming impacts on water resources and ecology of a river basin in Japan. J. Hydro-Environ. Res. 2008, 1, 164-175. [CrossRef]

32. Qi, W.; Liu, J.; Leung, F. A framework to quantify impacts of elevated $\mathrm{CO}_{2}$ concentration, global warming and leaf area changes on seasonal variations of water resources on a river basin scale. J. Hydrol. 2019, 570, 508-522. [CrossRef]

33. Morini, E.; Touchaei, A.G.; Rossi, F.; Cotana, F.; Akbari, H. Evaluation of albedo enhancement to mitigate impacts of urban heat island in Rome (Italy) using WRF meteorological model. Urban Clim. 2018, 24, 551-566. [CrossRef]

34. Filho, W.L.; Icaza, L.E.; Neht, A.; Klavins, M.; Morgan, E.A. Coping with the impacts of urban heat islands. A literature based study on understanding urban heat vulnerability and the need for resilience in cities in a global climate change context. J. Clean. Prod. 2018, 171, 1140-1149. [CrossRef]

35. Guilbert, D.; Caluwaerts, S.; Calle, K.; Bossche, N.V.D.; Cnudde, V.; De Kock, T. Impact of the urban heat island on freeze-thaw risk of natural stone in the built environment, a case study in Ghent, Belgium. Sci. Total Environ. 2019, 677, 9-18. [CrossRef] 
36. Li, Y.; Liu, Y.; Long, H.; Cui, W. Community-based rural residential land consolidation and allocation can help to revitalize hollowed villages in traditional agricultural areas of China: Evidence from Dancheng County. Henan Province. Land Use Policy 2014, 39, 188-198. [CrossRef]

37. Langevin, J.; Harris, C.B.; Reyna, J.L. Assessing the Potential to Reduce, U.S. Building $\mathrm{CO}_{2}$ Emissions $80 \%$ by 2050. Joule 2019, 3, 2403-2424. [CrossRef]

38. Sun, L.; Zhou, K.; Yang, S. Regional difference of household electricity consumption: An empirical study of Jiangsu, China. J. Clean. Prod. 2018, 171, 1415-1428. [CrossRef]

39. An, J.H.; Bae, S.G.; Choi, J.; Lee, M.G.; Oh, H.S.; Yun, D.Y.; Lee, D.-E.; Park, H.S. Sustainable design model for analysis of relationships among building height, $\mathrm{CO}_{2}$ emissions, and cost of core walls in office buildings in Korea. Build. Environ. 2019, 150, 289-296. [CrossRef]

40. Huang, P.J.; Huang, S.L.; Marcotullio, P.J. Relationships between $\mathrm{CO}_{2}$ emissions and embodied energy in building construction: A historical analysis of Taipei. Build. Environ. 2019, 155, 360-375. [CrossRef]

41. Bourdeau, M.; Guo, X.; Nefzaoui, E. Buildings energy consumption generation gap: A post-occupancy assessment in a case study of three higher education buildings. Energy Build. 2018, 159, 600-611. [CrossRef]

42. Ma, H.; Li, C.; Lai, J.; Yang, F.; Li, Z. Investigation on energy consumption of public buildings in Tianjin. Energy Procedia. 2019, 158, 3427-3432. [CrossRef]

43. Hong, B.; Lin, B.; Qin, H. Numerical investigation on the coupled effects of building-tree arrangements on fine particulate matter (PM2.5) dispersion in housing blocks. Sustain. Cities Soc. 2017, 34, 358-370. [CrossRef]

44. Martins, N.R.; Graça, G.C. Impact of PM2.5 in indoor urban environments: A review. Sustain. Cities Soc. 2018, 42, 259-275. [CrossRef]

45. Sajani, S.Z.; Marchesi, S.; Trentini, A.; Bacco, D.; Zigola, C.; Rovelli, S.; Ricciardelli, I.; Maccone, C.; Lauriola, P.; Cavallo, D.M.; et al. Vertical variation of PM2.5 mass and chemical composition, particle size distribution, NO2, and BTEX at a high rise building. Environ. Pollut. 2018, 235, 339-349. [CrossRef]

46. Building Carbon Rmissions Constitute One-Third of National Carbon Emissions, Increasing Urgency for Green Building Development. 2018. Available online: http://www.tanpaifang.com/lvsejianzhu/201811/0562431.html (accessed on 22 September 2021).

47. Ministry of Housing and Urban-Rural Development, 2019 Building Carbon Emission Calculation Standards. 2019. Available online: http:/ / www.zhaojianzhu.com/guojiaguifan/255199.html (accessed on 22 September 2021).

48. Chyxx, 2018 Analysis On the Current Condition and Trend of Building Industry Development in China. 2019. Available online: http:/ / www.chyxx.com/industry/201910/799534.html (accessed on 22 September 2021).

49. Robinson, C.; Dilkina, B.; Hubbs, J.; Zhang, W.; Guhathakurta, S.; Brown, M.A.; Pendyala, R.M. Machine learning approaches for estimating commercial building energy consumption. Appl. Energ. 2017, 208, 889-904. [CrossRef]

50. Shazmin, S.A.A.; Sipan, I.; Sapri, M. Property tax assessment incentives for green building: A review. Renew. Sustain. Energy Rev. 2016, 60, 536-548. [CrossRef]

51. Kim, M.J. Characteristics and determinants by electricity consumption level of households in Korea. Energy Rep. 2018, 4, 70-76. [CrossRef]

52. Zhang, Y.; Wang, J.; Hu, F.; Wang, Y. Comparison of evaluation standards for green building in China, Britain, United States. Renew. Sustain. Energy Rev. 2017, 68, 262-271. [CrossRef]

53. Yin, S.; Li, B.; Xing, Z. The governance mechanism of the building material industry (BMI) in transformation to green BMI: The perspective of green building. Sci. Total Environ. 2019, 677, 19-33. [CrossRef]

54. Zhang, X.; Dong, Q.; Costa, V.; Wang, X. A hierarchical Bayesian model for decomposing the impacts of human activities and climate change on water resources in China. Sci. Total Environ. 2019, 665, 836-847. [CrossRef]

55. Shafique, M.; Kim, R.; Rafiq, M. Green roof benefits, opportunities and challenges-A review. Renew. Sustain. Energy Rev. 2018, 90, 757-773. [CrossRef]

56. Besir, A.B.; Cuce, E. Green roofs and facades: A comprehensive review. Renew. Sustain. Energy Rev. 2018, 82, 915-939. [CrossRef]

57. Jusselme, M.D.; Pruvost, C.; Motar, E.; Giusti-Miller, S.; Frechault, S.; Alphonse, V.; Bi, C.B.B.; Dajoz, I.; Mora, P. Increasing the ability of a green roof to provide ecosystem services by adding organic matter and earthworms. Appl. Soil Ecol. 2019, 143, 61-69. [CrossRef]

58. Zhou, S.Y.D.; Zhang, Q.; Neilson, R.; Giles, M.; Li, H.; Yang, X.R.; Su, J.Q.; Zhu, Y.G. Vertical distribution of antibiotic resistance genes in an urban green façade. Environ. Int. 2021, 152, 106502. [CrossRef]

59. Tomson, M.; Kumar, P.; Barwise, Y.; Perez, P.; Forehead, H.; French, K.; Morawska, L.; Watts, J.F. Green infrastructure for air quality improvement in street canyons. Environ. Int. 2021, 146, 106288. [CrossRef]

60. Rosas-Flores, J.A.; Zenón-Olvera, E.; Gálvez, D.M. Potential energy saving in urban and rural households of Mexico with solar photovoltaic systems using geographical information system. Renew. Sustain. Energy Rev. 2019, 116, 109412. [CrossRef]

61. Trindade, A.; Cordeiro, L. Automated formal verification of stand-alone solar photovoltaic systems. Sol. Energy. 2019, 193, 684-691. [CrossRef]

62. Leite, G.N.P.; Weschenfelder, F.; Araújo, A.M.; Ochoa, Á.A.V.; Kraj, A. An economic analysis of the integration between airconditioning and solar photovoltaic systems. Energ. Convers. Manage. 2019, 185, 836-849. [CrossRef]

63. Missoum, A.; Elmir, M.; Belkacem, A.; Nabou, M.; Draoui, B. Numerical Simulation of Heat Transfer through a Double-walled Facade Building in Arid Zone. Energy Procedia. 2013, 36, 834-843. [CrossRef] 
64. Inan, T.; Basaran, T. Experimental and numerical investigation of forced convection in a double skin façade by using nodal network approach for Istanbul. Sol. Energy. 2019, 183, 441-452. [CrossRef]

65. Lago, T.G.S.; Ismail, K.A.R.; Lino, F.A.M. Ventilated double glass window with reflective film: Modeling and assessment of performance. Sol. Energy. 2019, 185, 72-88. [CrossRef]

66. González-Julián, E.; Xamán, J.; Moraga, N.O.; Chávez, Y.; Zavala-Guillén, I.; Simá, E. Annual thermal evaluation of a double pane window using glazing available in the Mexican market. Appl. Therm. Eng. 2018, 143, 100-111. [CrossRef]

67. Xue, P.; Li, Q.; Xie, J.; Zhao, M.; Liu, J. Optimization of window-to-wall ratio with sunshades in China low latitude region considering daylighting and energy saving requirements. Appl. Energ. 2019, 233-234, 62-70. [CrossRef]

68. Richter, J.L.; Tähkämö, L.; Dalhammar, C. Trade-offs with longer lifetimes? The case of LED lamps considering product development and energy contexts. J. Clean. Prod. 2019, 226, 195-209. [CrossRef]

69. Gautam, A.; Chamoli, S.; Kumar, A.; Singh, S. A review on technical improvements, economic feasibility and world scenario of solar water heating system. Renew. Sustain. Energy Rev. 2017, 68, 541-562. [CrossRef]

70. Choi, Y.; Mae, M.; Kim, H.B. Thermal performance improvement method for air-based solar heating systems. Sol. Energy. 2019, 186, 277-290. [CrossRef]

71. Lu, Y.; Tian, Z.; Peng, P.; Niu, J.; Li, W.; Zhang, H. GMM clustering for heating load patterns in-depth identification and prediction model accuracy improvement of district heating system. Energy Build. 2019, 190, 49-60. [CrossRef]

72. Risbeck, M.J.; Maravelias, C.T.; Rawlings, J.B.; Turney, R.D. A mixed-integer linear programming model for real-time cost optimization of building heating, ventilation, and air conditioning equipment. Energy Build. 2017, 142, 220-235. [CrossRef]

73. Heiskanen, E.; Matschoss, K. Understanding the uneven diffusion of building-scale renewable energy systems: A review of household, local and country level factors in diverse European countries. Renew. Sustain. Energy Rev. 2017, 75, 580-591. [CrossRef]

74. Xiangyang HURDB, 2019 Announcement on Subsidies for Energy Conservation Renovation in Household Buildings. 2019. Available online: http://szjj.xiangyang.gov.cn/zwgk/gkml/gsgg/201912/t20191210_1987096.shtml (accessed on 22 September 2021).

75. Sun, C.; Zhang, J.; Guo, Y.; Fu, Q.; Liu, W.; Pan, J.; Huang, Y.; Zou, Z.; Huang, C. Outdoor air pollution in relation to sick building syndrome (SBS) symptoms among residents in Shanghai, China. Energy Build. 2018, 174, 68-76. [CrossRef]

76. Meng, M.; Wang, L.; Shang, W. Decomposition and forecasting analysis of China's household electricity consumption using three-dimensional decomposition and hybrid trend extrapolation models. Energy 2018, 165, 143-152. [CrossRef]

77. Ordos Housing and Urban-Rural Development Bureau, 2019 Public Announcement on Applying for Renovation Items for Existing Household Buildings. 2019. Available online: http://zjj.ordos.gov.cn/tzgg_77006/201904/t20190429_2369438.html (accessed on 22 September 2021).

78. Wu, S.; Zheng, X.; You, C.; Wei, C. Household energy consumption in rural China: Historical development, present pattern and policy implication. J. Clean. Prod. 2019, 211, 981-991. [CrossRef]

79. Niu, S.; Li, Z.; Qiu, X.; Dai, R.; Hong, Z. Measurement of effective energy consumption in China's rural household sector and policy implication. Energ. Policy. 2019, 128, 553-564. [CrossRef]

80. Kim, H.; Jung, T.Y. Independent solar photovoltaic with Energy Storage Systems (ESS) for rural electrification in Myanmar. Renew. Sustain. Energy Rev. 2018, 82, 1187-1194. [CrossRef]

81. China Electric Power News, 2019 Solar Photovoltaic Has Generated 19.1 GW to Aid Poverty! National Energy Administration Director Zhang Jianhua Announces Key Information on the 2020 National Energy Work Conference. 2019. Available online: https: / / news.solarbe.com/201912/17/318209.html (accessed on 22 September 2021).

82. Kurata, M.; Matsui, N.; Ikemoto, Y.; Tsuboi, H. Do determinants of adopting solar home systems differ between households and micro-enterprises? Evidence from rural Bangladesh. Renew. Energ. 2018, 129, 309-316. [CrossRef]

83. Ryan, A.M.; Spash, C.L.; Measham, T.G. Socio-economic and psychological predictors of domestic greywater and rainwater collection: Evidence from Australia. J. Hydrol. 2009, 379, 164-171. [CrossRef]

84. Villarreal, E.L.; Dixon, A. Analysis of a rainwater collection system for domestic water supply in Ringdansen, Norrköping, Sweden. Build. Environ. 2005, 40, 1174-1184. [CrossRef]

85. Şahin, N.İ.; Manioğlu, G. Water conservation through rainwater harvesting using different building forms in different climatic regions. Sustain. Cities Soc. 2019, 44, 367-377. [CrossRef]

86. Goonetilleke, A.; Liu, A.; Managi, S.; Wilson, C.; Gardner, T.; Bandala, E.R.; Walker, L.; Holden, J.; Wibowo, M.A.; Suripin, S.; et al. Stormwater reuse, a viable option: Fact or fiction? Econ. Anal. Policy. 2017, 56, 14-17. [CrossRef]

87. Hong, N.; Zhu, P.; Liu, A. Modelling heavy metals build-up on urban road surfaces for effective stormwater reuse strategy implementation. Environ. Pollut. 2017, 231, 821-828. [CrossRef]

88. Hong, N.; Liu, A.; Zhu, P.; Zhao, X.; Guan, Y.; Yang, M.; Wang, H. Modelling benzene series pollutants (BTEX) build-up loads on urban roads and their human health risks: Implications for stormwater reuse safety. Ecotoxicol. Environ. Saf. 2018, 164, 234-242. [CrossRef]

89. Coleman, S.; Hurley, S.; Rizzo, D.; Koliba, C.; Zia, A. From the household to watershed: A cross-scale analysis of residential intention to adopt green stormwater infrastructure. Landscape Urban Plan. 2018, 180, 195-206. [CrossRef]

90. Ashoori, N.; Teixido, M.; Spahr, S.; LeFevre, G.H.; Sedlak, D.L.; Luthy, R.G. Evaluation of pilot-scale biochar-amended woodchip bioreactors to remove nitrate, metals, and trace organic contaminants from urban stormwater runoff. Water Res. 2019, 154, 1-11. [CrossRef] 
91. Zou, B.; Luo, B. Rural household energy consumption characteristics and determinants in China. Energy 2019, 182, 814-823. [CrossRef]

92. Zhang, G.; Deng, N.; Mou, H.; Zhang, Z.G.; Chen, X. The impact of the policy and behavior of public participation on environmental governance performance: Empirical analysis based on provincial panel data in China. Energ. Policy. 2013, 129, 1347-1354. [CrossRef]

93. Hsueh, S.L.; Lin, Y.J. Critical Success Factors of the Urban Environmental Quality. Ekoloji 2018, 106, $217-222$.

94. Hsueh, S.L.; Su, F.L. Discussion of environmental education based on the social and cultural characteristics of the community-an MCDM approach. Appl. Ecol. Env. Res. 2017, 15, 183-196. [CrossRef]

95. Baumann, M.; Weil, M.; Peters, J.F.; Chibeles-Martins, N.; Moniz, A.B. A review of multi-criteria decision making approaches for evaluating energy storage systems for grid applications. Renew. Sustain. Energy Rev. 2019, 107, 516-534. [CrossRef]

96. Rosso-Cerón, A.M.; Kafarov, V.; Latorre-Bayona, G.; Quijano-Hurtado, R. A novel hybrid approach based on fuzzy multi-criteria decision-making tools for assessing sustainable alternatives of power generation in San Andrés Island. Renew. Sustain. Energy Rev. 2019, 110, 159-173. [CrossRef]

97. Khishtandar, S.; Zandieh, M.; Dorri, B. A multi criteria decision making framework for sustainability assessment of bioenergy production technologies with hesitant fuzzy linguistic term sets: The case of Iran. Renew. Sustain. Energy Rev. 2017, 77, 130-1145. [CrossRef]

98. Simsek, Y.; Watts, D.; Escobar, R. Sustainability evaluation of Concentrated Solar Power (CSP) projects under Clean Development Mechanism (CDM) by using Multi Criteria Decision Method (MCDM). Renew. Sustain. Energy Rev. 2018, 93, 421-438. [CrossRef]

99. Ferrer-Martí, L.; Ferrer, I.; Sánchez, E.; Garfí, M. A multi-criteria decision support tool for the assessment of household biogas digester programmes in rural areas. A case study in Peru. Renew. Sustain. Energy Rev. 2018, 95, 74-83. [CrossRef]

100. Balta, M.Ö.; Yenil, H.Ü. Multi criteria decision making methods for urban greenway: The case of Aksaray. Turkey. Land Use Policy 2019, 89, 104224. [CrossRef]

101. Manupati, V.K.; Ramkumar, M.; Samanta, D. A multi-criteria decision making approach for the urban renewal in Southern India. Sustain. Cities Soc. 2018, 42, 471-481. [CrossRef]

102. Kokaraki, N.; Hopfe, C.J.; Robinson, E.; Nikolaidou, E. Testing the reliability of deterministic multi-criteria decision-making methods using building performance simulation. Renew. Sustain. Energy Rev. 2019, 12, 991-1007. [CrossRef]

103. Alyami, S.H.; Rezgui, Y.; Kwan, A. Developing sustainable building assessment scheme for Saudi Arabia: Delphi consultation approach. Renew. Sustain. Energy Rev. 2013, 27, 43-54. [CrossRef]

104. Dantas, G.A.; Castro, N.J.; Dias, L.; Antunes, C.H.; Zamboni, L. Public policies for smart grids in Brazil. Renew. Sustain. Energy Rev. 2018, 92, 501-512. [CrossRef]

105. Prasad, R.D.; Bansal, R.C.; Raturi, A. Multi-faceted energy planning: A review. Renew. Sustain. Energy Rev. 2014, 38, 686-699. [CrossRef]

106. Jahanshahi, A.; Kamali, M.; Khalaj, M.; Khodaparast, Z. Delphi-based prioritization of economic criteria for development of wave and tidal energy technologies. Energy 2019, 167, 819-827. [CrossRef]

107. Kamaruzzaman, S.N.; Lou, E.C.W.; Wong, P.F.; Edwards, R.; Ghani, M.K. Development of a non-domestic building refurbishment scheme for Malaysia: A Delphi approach. Energy 2019, 167, 804-818. [CrossRef]

108. Zadeh, L.A. Fuzzy sets. Inf. Control. 1965, 8, 338-353. [CrossRef]

109. Zadeh, L.A. Fuzzy logic = Computing with words. IEEE Trans. on Fuzzy Syst. 1996, 4, 103-111. [CrossRef]

110. Liu, G.; Baniyounes, A.; Rasul, M.G.; Amanullah, M.T.O.; Khan, M.M.K. Fuzzy Logic based Environmental Indicator for Sustainability Assessment of Renewable Energy System using Life Cycle Assessment. Procedia Eng. 2012, 49, 35-41. [CrossRef]

111. Abouelnaga, A.E.; Metwally, A.; Aly, N.; Nagy, M.; Agamy, S. Assessment of nuclear energy sustainability index using fuzzy logic. Nucl. Eng. Des. 2010, 240, 1928-1933. [CrossRef]

112. Vigneysh, T.; Kumarappan, N. Grid interconnection of renewable energy sources using multifunctional grid-interactive converters: A fuzzy logic based approach. Electr. Pow. Syst. Res. 2017, 151, 359-368. [CrossRef]

113. Pislaru, M.; Herghiligiu, I.V.; Robu, I.B. Corporate sustainable performance assessment based on fuzzy logic. J. Clean. Prod. 2019, 223, 998-1013. [CrossRef]

114. Azizkhani, M.; Vakili, A.; Noorollahi, Y.; Naseri, F. Potential survey of photovoltaic power plants using Analytical Hierarchy Process (AHP) method in Iran. Renew. Sustain. Energy Rev. 2017, 75, 1198-1206. [CrossRef]

115. Ghimire, L.P.; Kim, Y. Ananalysis on barriers to renewable energy development in the context of Nepal using AHP. Renew. Energ. 2018, 129, 446-456. [CrossRef]

116. Salvia, A.L.; Brandli, L.L.; Filho, W.L.; Kalil, R.M.L. An analysis of the applications of Analytic Hierarchy Process (AHP) for selection of energy efficiency practices in public lighting in a sample of Brazilian cities. Energ. Policy. 2019, 132, 854-864. [CrossRef]

117. Ocampo-Duque, W.; Ferré-Huguet, N.; Domingo, J.L.; Schuhmacher, M. Assessing water quality in rivers with fuzzy inference systems: A case study. Environ. Int. 2016, 32, 733-742. [CrossRef]

118. Topuz, E.; Gestel, C.A.M. An approach for environmental risk assessment of engineered nanomaterials using Analytical Hierarchy Process $(A H P)$ and fuzzy inference rules. Environ. Int. 2016, 92-93, 334-347. [CrossRef] 